\title{
Cross-formational flow and salinity sources inferred from a combined study of helium concentrations, isotopic ratios, and major elements in the Marshall aquifer, southern Michigan
}

\author{
Lin Ma, Maria Clara Castro, Chris Michael Hall, and Lynn M. Walter \\ Department of Geological Sciences, University of Michigan, 2534 C. C. Little Building, Ann Arbor, Michigan 48109- \\ 1005, USA (linma@umich.edu)
}

[1] Helium data and major ion chemistry are presented for the shallow Marshall aquifer in southern Michigan. This data set is subsequently analyzed in conjunction with major element data sets from deeper and shallower water levels previously collected in this area. He excesses and isotopic ratios suggest the presence of tritiogenic ${ }^{3} \mathrm{He}$ in young waters in the Marshall aquifer. He excesses in old groundwater samples are mostly of crustal origin although the presence of a significant mantle He component in some samples cannot be ruled out. He excesses in the Marshall aquifer are unusually high for such shallow depths $(\leq 300 \mathrm{~m})$ and reach over two and three orders of magnitude above those of air-saturated water (ASW) for ${ }^{3} \mathrm{He}$ and ${ }^{4} \mathrm{He}$, respectively. He isotopes require a source external to the aquifer, partly supplied by underlying formations within the sedimentary sequence, partly from the crystalline basement. Calibration of He concentrations observed in the Marshall aquifer requires He fluxes of $1 \times 10^{-13}$ and $1.6 \times 10^{-6} \mathrm{~cm}^{3} \mathrm{STP} \mathrm{cm}{ }^{-2} \mathrm{yr}^{-1}$ for ${ }^{3} \mathrm{He}$ and ${ }^{4} \mathrm{He}$, respectively. These He fluxes are far greater than those reported in other sedimentary basins around the world (e.g., Paris Basin, Gulf Coast Basin) at similar and far greater depths. Such high He fluxes present at such shallow depths within the Michigan Basin strongly suggest the presence of a dominant vertical water flow component and further indicate that impact of recharge water at depth is minor. Upward cross-formational flow is also likely responsible for the extremely high salinities present in the shallow subsurface of the Michigan Basin. The observed positive correlation between helium and bromide strongly suggests that these two very distinct conservative tracers both originate at greater depths and further suggests that advection is the dominant transport mechanism within the basin. The occurrence of large-scale cross-formational flow is also consistent with the evolution displayed by the major ion chemistry throughout most of the sedimentary sequence, indicating that solutes from shallow levels carry the signature of deep formation brines.

Components: 11,311 words, 9 figures, 3 tables.

Keywords: basinal brines; cross-formational flow; He fluxes; multilayered sedimentary basins.

Index Terms: 1832 Hydrology: Groundwater transport; 1829 Hydrology: Groundwater hydrology; 1040 Geochemistry: Radiogenic isotope geochemistry.

Received 29 April 2005; Revised 17 July 2005; Accepted 10 August 2005; Published 8 October 2005.

Ma, L., M. C. Castro, C. M. Hall, and L. M. Walter (2005), Cross-formational flow and salinity sources inferred from a combined study of helium concentrations, isotopic ratios, and major elements in the Marshall aquifer, southern Michigan, Geochem. Geophys. Geosyst., 6, Q10004, doi:10.1029/2005GC001010.

\section{Introduction}

[2] Subsurface fluids presenting high salinities are a common occurrence in sedimentary basins at great depths (e.g., Gulf Coast Basin, Illinois Basin, Paris Basin) [Carpenter, 1978; Stueber and Walter, 1991; Fontes and Matray, 1993]. By contrast, high salinity fluids are found at all 
depths in the Michigan Basin, from the deep Ordovician St. Peters Sandstone up to the very shallowest subsurface levels (Glacial Drift) [Long et al., 1988; Wilson, 1989]. In addition to its ubiquitous distribution, some of these high salinity fluids in the Michigan Basin also present some rather unusual characteristics. For example, fluids from the Lower Devonian-Silurian formations $(1 \mathrm{~km} \leq$ depth $\leq 2 \mathrm{~km})$ yield some of the highest salinities (total dissolved solids: TDS > $450 \mathrm{~g} / \mathrm{L}$ ) reported in sedimentary basins around the world, and contain high concentrations of $\mathrm{Ca}^{2+}, \mathrm{Br}^{-}$and $\mathrm{Cl}^{-}$, as well as low $\mathrm{Mg}^{2+}, \mathrm{SO}_{4}^{2-}$, and $\mathrm{HCO}_{3}^{-}$[Wilson and Long, 1993a]. Salinities up to $200 \mathrm{~g} / \mathrm{L}$ are also found in aquifers and aquitards of the Carboniferous-Upper Devonian formations at shallow depths $(<300 \mathrm{~m})$ [Martini, 1997]. The origin of such high salinities, however, remains uncertain and has been the focus of numerous studies [e.g., Long et al., 1988; Wilson, 1989; Wilson and Long, 1993a, 1993b; Ging et al., 1996; Martini, 1997; McIntosh et al., 2004]. Indeed, while Lower Devonian-Silurian brines (e.g., Detroit River Group, Niagara/Salina Formation) evolved most likely from evaporated concentrated seawater subsequently modified by water-rock interactions [Wilson and Long, 1993a], evolution of shallow Carboniferous-Upper Devonian formation fluids (e.g., Marshall Sandstone, Antrim Shale, Traverse Formation) does not appear to support extreme seawater evaporation [Long et al., 1988; Wilson and Long, 1993b; Ging et al., 1996; McIntosh et al., 2004]. Although dissolution of evaporites in neighboring formations may explain some of the high salinities observed locally in some shallow formations (e.g., Antrim Formation waters in the northern marginal basin [McIntosh et al., 2004]), such a process, however, cannot account for the high $\mathrm{Br}^{-}$concentrations commonly found in these waters [e.g., Long et al., 1988; Ging et al., 1996].

[3] Upward transport of deep basinal brines and subsequent mixing with meteoric water has been previously proposed to account for the presence of such high salinity waters in near-surface environments in the Michigan Basin [Long et al., 1988; Mandle and Westjohn, 1989; Weaver et al., 1995; Kolak et al., 1999; McIntosh et al., 2004]. Such upward transport, however, has not been confirmed.

[4] The study of helium isotopes in large-scale groundwater flow systems offers a powerful tool to investigate cross-formational flow within sedimentary basins [see, e.g., Castro et al., 1998a, 1998b; Castro and Goblet, 2003; Patriarche et al., 2004]. Helium isotopes can thus be used to ascertain whether or not cross-formational flow, i.e., upward leakage, is occurring through the entire sedimentary sequence in the Michigan Basin, therefore better constraining the origin of the very high salinities present at all levels and, more specifically, in shallow groundwater systems.

[5] Because of its conservative nature, helium is transported in and by the water without reacting with the reservoir rocks. Typically, helium is present in the mantle (e.g., primordial origin), in the crust (nucleogenic and radiogenic origin), and in the atmosphere (as a consequence of the degassing of the Earth). These components of different origin present specific characteristics, which allow identification of their sources and sinks [e.g., Stute et al., 1992; Hilton and Porcelli, 2003; Castro, 2004; Saar et al., 2005]. Concentrations of $\mathrm{He}$ isotopes $\left({ }^{3} \mathrm{He},{ }^{4} \mathrm{He}\right)$ in groundwater frequently exceed those expected for water in solubility equilibrium with the atmosphere (air-saturated water: ASW). These excesses can result from different sources: (1) an excess air component resulting from dissolution of small air bubbles caused by fluctuations of the groundwater table [Heaton and Vogel, 1981]; (2) the $\beta$-decay of natural and bomb tritium (tritiogenic $\left.{ }^{3} \mathrm{He}\right)$; (3) the ${ }^{6} \mathrm{Li}(\mathrm{n}, \alpha)^{3} \mathrm{H}\left({ }^{3} \mathrm{He}\right)$ reaction [Morrison and Pine, 1955] (nucleogenic ${ }^{3} \mathrm{He}$ ); (4) the $\alpha$-decay of the natural $U$ and Th decay series elements (radiogenic ${ }^{4} \mathrm{He}$ ); and (5) mantle contributions to both ${ }^{3} \mathrm{He}$ and ${ }^{4} \mathrm{He}$.

[6] In this contribution, we present helium data and major ion chemistry from the Marshall aquifer in southern Michigan. This shallow groundwater data set is subsequently analyzed in conjunction with major element data sets from deeper and shallower water levels previously acquired in this area [Dannemiller and Baltusis, 1990; Wilson and Long, 1993a, 1993b; McIntosh et al., 2004]. In a similar manner to that of observed high salinities, it will be shown that $\mathrm{He}$ excesses in the Marshall aquifer are unusually high for such shallow depths. Such high excesses require an external helium source to the aquifer, partly supplied by underlying formations within the sedimentary sequence, partly from the crystalline basement. The positive correlation observed between helium and bromide strongly suggests that these two very distinct conservative tracers both originate at greater depths, and further suggests that advection is the dominant transport mechanism within the basin. Our findings reinforce the notion that upward leakage is the main 
process responsible for the presence of such high salinities at shallow depths. The latter is also consistent with the evolution displayed by the major ion chemistry through most of the sedimentary sequence, indicating that solutes from shallow levels carry the signature of deep formation brines.

[7] This study aims at illustrating the practical gains achieved at clarifying the nature of crossformational flow as well as the origin of high salinity fluids through the combined use of helium isotopes and major ion chemistry.

\section{Geological and Hydrogeologic Background}

[8] Located in the northeastern United States, the Michigan Basin is a concentric intracratonic depression floored by crystalline Precambrian basement (Figures 1a, 1b, and 1c), and consists of a succession of sedimentary rocks from Precambrian to Jurassic that reaches depths over $5 \mathrm{~km}$ [Dorr and Eschman, 1970; Catacosinos and Daniels, 1991]. The entire sedimentary strata are covered by thick Pleistocene Glacial Drift sediments and are composed mainly of evaporites (e.g., Salina Group), carbonates (e.g., Traverse Formation), shales (e.g., Antrim and Coldwater Formations), and sandstones (e.g., Marshall Formation) (Figure 1c). Depending on its nature, these sedimentary rocks constitute either aquitards (e.g., shale, evaporites) or aquifers (mostly sandstones and reefal and dolomitized limestones), giving origin to a multilayered aquifer system [Vugrinovich, 1986; Westjohn and Weaver, 1996].

[9] Major tectonic structures such as the AlbionScipio Fault, the Lucas Fault, and the Howell Anticline (Figure 1a) are present in southern Michigan and penetrate also the Precambrian crystalline basement [Fisher et al., 1988]. The latter belongs to the Eastern Granite and Rhyolite Province (EGRP), and displays an age of $\sim 1.5 \mathrm{Ga}$ [Hinze et al., 1975; Van Schmus, 1992; Menuge et al., 2002].

[10] The Marshall aquifer, a major groundwater flow system composed mostly of sandstones of Mississippian age, is located in the central portion of the Michigan Basin (Figures 1a, 1c, and 2). The Bayport-Michigan confining units which are composed mostly of shale and limestone overly the Marshall aquifer, which in turn overlies the Coldwater and Antrim Shale confining units (Figure 1c). These formations subcrop at an altitude of $\sim 300 \mathrm{~m}$.
In the Marshall aquifer in southern Michigan, groundwater flows gravitationally to the NE and NW (Figure 2), and groundwater discharges into Lake Huron and Lake Michigan, in the Saginaw and Michigan Lowlands area, respectively [Vugrinovich, 1986; Mandle and Westjohn, 1989]. Salinities increase from the recharge (TDS $\leq 0.5 \mathrm{~g} / \mathrm{L}$ ) toward the discharge areas (TDS $\geq 200 \mathrm{~g} / \mathrm{L}$ ).

\section{Sampling Techniques and Experimental Methods}

[11] Water samples for analysis of noble gases (He, $\mathrm{Ne}, \mathrm{Ar}, \mathrm{Kr}$ and $\mathrm{Xe}$ ) were colleted from 14 wells in the Marshall aquifer (Figure 2) after temperature and $\mathrm{pH}$ reached equilibrium. Samples were collected in copper tubes (i.e., standard refrigeration grade $3 / 8^{\prime \prime} \mathrm{Cu}$ tubing) and water was allowed to flow through for $\sim 10$ minutes. While the water flushed through the system, the absence of gas bubbles that could potentially contaminate or phase fractionate the samples was checked through a transparent plastic tube mounted at the end of the $\mathrm{Cu}$ tube. The $\mathrm{Cu}$ tubes were then sealed by stainless steel pinch-off clamps [Weiss, 1968]. Noble gases were analyzed at the Noble Gas Laboratory at the University of Michigan as described briefly below and in detail by $M a$ et al. [2004] and Saar et al. [2005].

[12] Water samples in $\mathrm{Cu}$ tubes were attached to a vacuum extraction system and noble gases were quantitatively extracted for inletting into a MAP215 mass spectrometer. Noble gases were transported using water vapor as a carrier gas through two constrictions in the vacuum system, purified, and sequentially allowed to enter a MAP-215 mass spectrometer using a cryo-separator. The complete measurement procedure comprises estimation of $\mathrm{He}, \mathrm{Ne}, \mathrm{Ar}, \mathrm{Kr}$, and $\mathrm{Xe}$ concentrations, and their respective isotopic ratios, with standard errors for volume estimates of $1.5,1.3,1.3,1.5$ and $2.2 \%$, respectively. When replicate analyses are available, an error weighted average is reported.

[13] Water samples collected for analyses of major elements were filtered with a $0.45 \mu \mathrm{m}$ Gelman Laboratory AquaPrep filter, and subsequently preserved in high-density polyethylene bottles with no head space before analyses. Samples for cation analyses were acidified to $\mathrm{pH}<2$ by using nitric acid. Major ion chemistry of these samples was determined in the Experimental and Aqueous Geochemistry Laboratory at the University of 

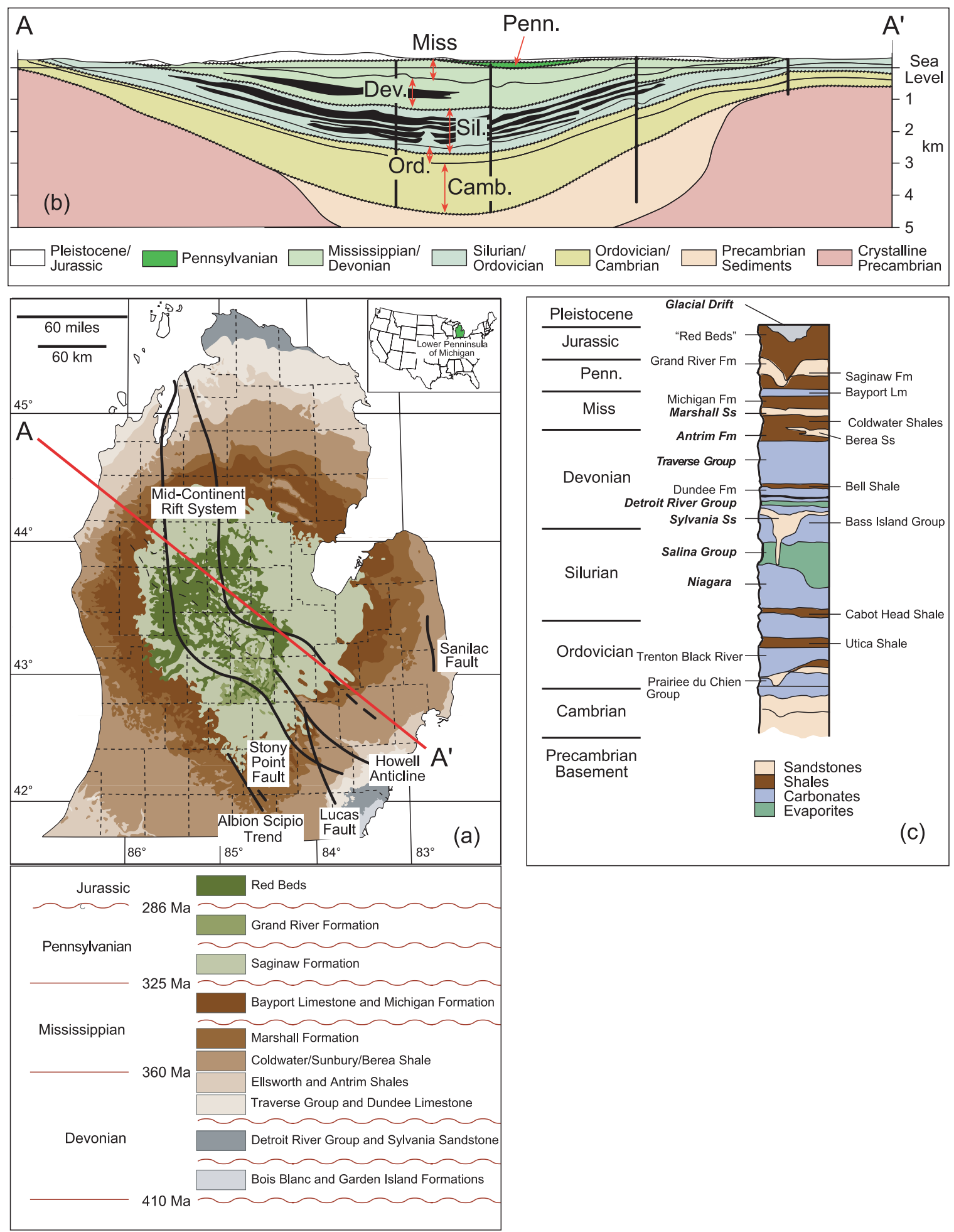

Figure 1. (a) Subcrop formations and major structures present in the Michigan Basin-Lower Peninsula of Michigan [after Dorr and Eschman, 1970; Fisher et al., 1988]; (b) general schematic geologic representation along cross section $\mathrm{A}-\mathrm{A}^{\prime}$; (c) stratigraphic succession through the Michigan Basin in which major lithologies present in the basin are identified; units for which chemistry of formation waters is discussed in this study are indicated (bold italic). 


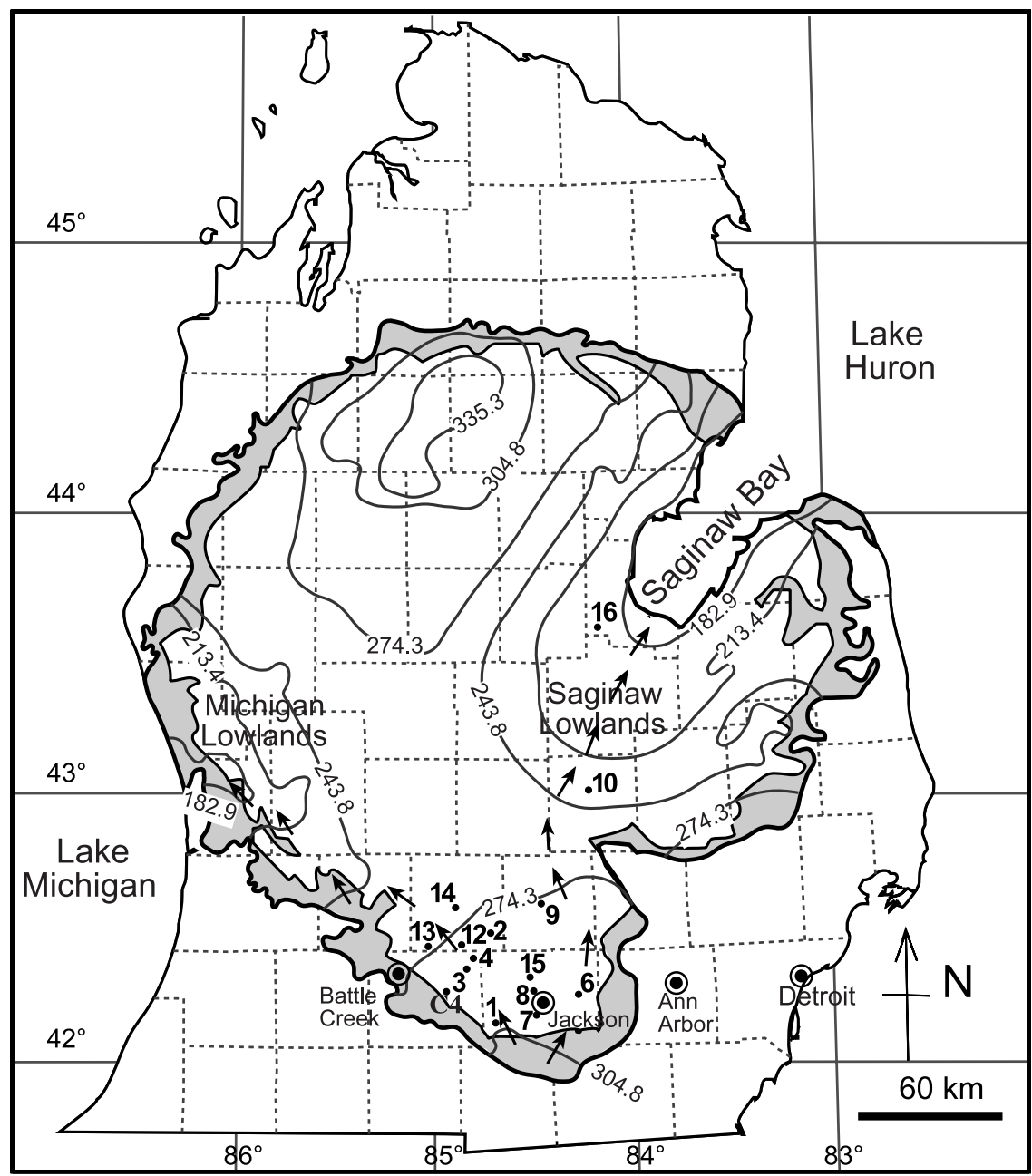

Figure 2. Detailed study area and sample locations for the Marshall aquifer in southern Michigan [adapted from Mandle and Westjohn, 1989]. The Marshall aquifer subcrop (shaded area), equipotentials (m, contour lines), and direction of water flow (arrows) are indicated, as well as the location of a groundwater sample for which tritium measurements are available (C4 [cf. Dannemiller and Baltusis, 1990]).

Michigan. Alkalinity was measured by the GranAlkalinity titration method [Gieskes and Rogers, 1973 ] with a precision of $\pm 0.4 \%$. Cation chemistry was determined by inductively coupled plasmaatomic emission spectrometry with a Leeman Labs PlasmaSpec III system (precision, $\pm 2 \%$ ). Anions were analyzed by ion chromatograpgy (IC) with a Dionex 4000I series (precision, $\pm 1 \%$ ).

\section{Helium Systematics}

[14] Excess $\mathrm{He}\left(H e_{e x c}\right)$ is calculated by removing the ASW $\left(H e_{e q}\right)$ and excess air $\left(H e_{e a}\right)$ components from total measured He concentrations $\left(H_{\text {meas }}\right)$ in water samples [cf. Stute et al., 1992; Castro et al., 2000]. $\mathrm{He}_{e q}$ and $\mathrm{He}_{e a}$ are estimated on the basis of recharge temperatures derived from $\mathrm{Ne}, \mathrm{Ar}, \mathrm{Kr}$, and Xe concentrations previously reported by Ma et al.
[2004] and following Ballentine and Hall [1999]. $H e_{e x c}$ comprises both mantle $\left(H e_{m}\right)$ and crustal $\left(H e_{c}=H e_{c i n}+H e_{c e x t}\right)$ components, where $H e_{\text {cin }}$ and $H e_{\text {cext }}$ are produced in situ within the aquifer and externally at greater depths, respectively, and ${ }^{3} \mathrm{He}_{t}$ is the tritiogenic ${ }^{3} \mathrm{He}$, so that

$$
\begin{aligned}
{ }^{3} \mathrm{He}_{\text {exc }} & ={ }^{3} \mathrm{He}_{\text {meas }}-{ }^{3} \mathrm{He}_{\text {eq }}-{ }^{3} \mathrm{He}_{\text {ea }} \\
& ={ }^{3} \mathrm{He}_{\text {cin }}+{ }^{3} \mathrm{He}_{\text {cext }}+{ }^{3} \mathrm{He}_{m}+{ }^{3} \mathrm{He}_{t}
\end{aligned}
$$

and

$$
\begin{aligned}
{ }^{4} H e_{e x c} & ={ }^{4} H e_{\text {meas }}-{ }^{4} H e_{e q}-{ }^{4} \mathrm{He}_{e a} \\
& ={ }^{4} \mathrm{He}_{\text {cin }}+{ }^{4} \mathrm{He}_{\text {cext }}+{ }^{4} \mathrm{He}_{m}
\end{aligned} .
$$

Concentrations of ${ }^{3} \mathrm{He}$ in equation (1) are given by ${ }^{3} \mathrm{He}_{e q}={ }^{4} \mathrm{He}_{e q} \times \mathrm{R}_{e q},{ }^{3} \mathrm{He}_{e a}={ }^{4} \mathrm{He} e_{e a} \times \mathrm{R}_{a}$, and ${ }^{3} \mathrm{He}_{\text {meas }}={ }^{4} \mathrm{He}$ meas $\times R_{\text {meas }}$, where $R_{\text {eq }}=$ 
$(1.360 \pm 0.006) \times 10^{-6}$ is the ${ }^{3} \mathrm{He} /{ }^{4} \mathrm{He}$ ratio for ASW [Benson and Krause, 1980], $R_{a}=(1.384 \pm$ $0.013) \times 10^{-6}$ is the atmospheric ${ }^{3} \mathrm{He} /{ }^{4} \mathrm{He}$ ratio [Clarke et al., 1976], and $R_{\text {meas }}$ is the total measured ${ }^{3} \mathrm{He} /{ }^{4} \mathrm{He}$ ratio. We also define

$R_{e x c}=\frac{{ }^{3} H e_{e x c}}{{ }^{4} H e_{e x c}} \quad R_{c}=\frac{{ }^{3} H e_{\text {cin }}+{ }^{3} H e_{\text {cext }}}{{ }^{4} H e_{\text {cin }}+{ }^{4} H e_{\text {cext }}} \quad R_{m}=\frac{{ }^{3} H e_{m}}{{ }^{4} H e_{m}}$.

\section{Marshall Aquifer: Results and Discussion}

\subsection{General Data Overview}

[15] He concentrations and isotopic ratios, ${ }^{14} \mathrm{C}$ and calendar ages, $\mathrm{pH}$, temperature, major element data, as well as sample names, locations, and well depths are given in Tables 1 and 2, respectively. ${ }^{14} \mathrm{C}$ ages were estimated according to Fontes and Garnier's [1979] correction model and a half-life value of 5730 years was used as suggested by these authors. ${ }^{14} \mathrm{C}$ ages were subsequently converted into calendar ages using CALIB Rev4.4.1 [Stuiver and Reimer, 1993]. Additional details on ${ }^{14} \mathrm{C}$ age estimation can be found at Ma et al. [2004].

[16] For most of the Marshall groundwater samples, ${ }^{3} \mathrm{He}$ and ${ }^{4} \mathrm{He}$ concentrations are found in excess of those expected for water in solubility equilibrium with the atmosphere (Table 1). He excesses vary and are greater for ${ }^{4} \mathrm{He}$ than for ${ }^{3} \mathrm{He}$. These excesses reach values of over two and three orders of magnitude above those of ASW for ${ }^{3} \mathrm{He}$ and ${ }^{4} \mathrm{He}$, respectively, and are particularly high for sample 16, located in the Saginaw Lowland discharge area in the central portion of the basin (Figure 2). Similarly, $\mathrm{R}_{\mathrm{exc}} / \mathrm{R}_{\mathrm{a}}$ values vary from 5.78 to 0.03 , and are far greater for "modern waters" (samples 1, 3, 6-9, Table 1) as compared to older ones (e.g., samples 14a,b, 16, Table 1). The observed decrease in $R_{\text {exc }} / R_{a}$ values is accompanied by an increase in ${ }^{3} H e_{e x c}$ and ${ }^{4} H e_{e x c}$ (Figures $3 a$ and $3 b$ ).

[17] ${ }^{3} \mathrm{He}$ and ${ }^{4} \mathrm{He}$ excesses increase both with groundwater age and TDS (Tables 1 and 2). With the exception of samples $4 \mathrm{a}, \mathrm{b},{ }^{3} \mathrm{He}_{\text {exc }}$ and ${ }^{4} \mathrm{He}_{\text {exc }}$ increase almost linearly with groundwater ages (Figure 3c), and indicate a progressive accumulation of He isotopes in the Marshall aquifer over time. Approximate regional flow paths are indicated in Figure 2. Note, however, that distance from recharge areas to the different sample locations are highly variable due to the concentric shape of the Marshall subcrop (Figure 2). As a result, ground- water ages and corresponding $\mathrm{He}$ excesses of the different water samples reflect this variability. TDS values increase from $\sim 0.5 \mathrm{~g} / \mathrm{L}$ for samples located at the proximity of recharge areas ("modern waters") up to $217 \mathrm{~g} / \mathrm{L}$ for sample 16 , located in the Saginaw Lowland discharge area (Figure 2, Table 2). This progressive increase of $\mathrm{He}$ excess components as well as TDS is also accompanied by a marked evolution in water chemistry (Figure 3c). Specifically, young ("modern") waters display major-ion compositions dominated by a calciumbicarbonate $\left(\mathrm{Ca}-\mathrm{HCO}_{3}\right)$ facies, and evolve progressively into a dominantly sodium-bicarbonate $\left(\mathrm{Na}-\mathrm{HCO}_{3}\right)$ facies. As groundwater ages become older and salinity increases (e.g., samples 14, 15, 16), groundwater chemistry shifts progressively into a dominantly sodium-chloride $(\mathrm{Na}-\mathrm{Cl})$ facies. Samples 4a,b, with an unusual chemistry type and unusually high $\mathrm{He}$ excesses and $\mathrm{R}_{\mathrm{exc}} / \mathrm{R}_{\mathrm{a}}$ value as compared to its groundwater age are an exception to this pattern, and suggest a very distinct origin to these specific waters. This is discussed below.

\subsection{Excess ${ }^{3}$ He: Tritiogenic Versus Mantle and Crustal Components}

[18] While ${ }^{4} H e_{\text {exc }}$ present in most groundwaters has a dominant crustal origin [e.g., Castro et al., 1998a, 1998b, 2000], ${ }^{3} \mathrm{He}_{\text {exc }}$ can result from three distinct sources, i.e., from natural and/or bomb ${ }^{3} \mathrm{H}$ decay, in addition to a mantle and/or crustal origin. These three different ${ }^{3} \mathrm{He}$ sources can be identified partly on the basis of $R_{\text {exc }} / R_{a}$ values, ${ }^{3} \mathrm{He}$ and ${ }^{4} \mathrm{He}$ excesses, as well as on groundwater age considerations [e.g., see Saar et al., 2005]. For example, mantle-derived $\mathrm{He}$ is characterized by $8 \leq \mathrm{R}_{\mathrm{m}} / \mathrm{R}_{\mathrm{a}} \leq 30$ [e.g., Graham, 2002; Hilton and Porcelli, 2003] while very young waters carrying an important ${ }^{3} \mathrm{He}$ tritiogenic component can also yield $\mathrm{R}_{\mathrm{exc}} / \mathrm{R}_{\mathrm{a}}>1$ [Schlosser et al., 1989] (atmospheric ratio $\mathrm{R} / \mathrm{R}_{\mathrm{a}}=1$ ). By contrast, He produced in the crystalline crust as well as in shale dominated formations results in $0.02 \leq \mathrm{R}_{\mathrm{c}} / \mathrm{R}_{\mathrm{a}} \leq 0.05$ while typical in situ production in aquifers (e.g., sandstones, limestones) yields values of about one order of magnitude lower, with $0.001 \leq \mathrm{R}_{\mathrm{c}} / \mathrm{R}_{\mathrm{a}} \leq 0.005$ [e.g., Castro, 2004]. In the analysis that follows we adopt $0.02 \leq \mathrm{R}_{\text {exc }} / \mathrm{R}_{\mathrm{a}} \leq 0.05$ as our "reference" crustal value (Figures $3 \mathrm{a}$ and $3 \mathrm{~b}$ ). Thus $R_{\text {exc }} / R_{a}$ values greater than the latter strongly suggest the presence of a significant mantle or tritiogenic ${ }^{3} \mathrm{He}$ contribution. We attempt to identify these two distinct sources below. 


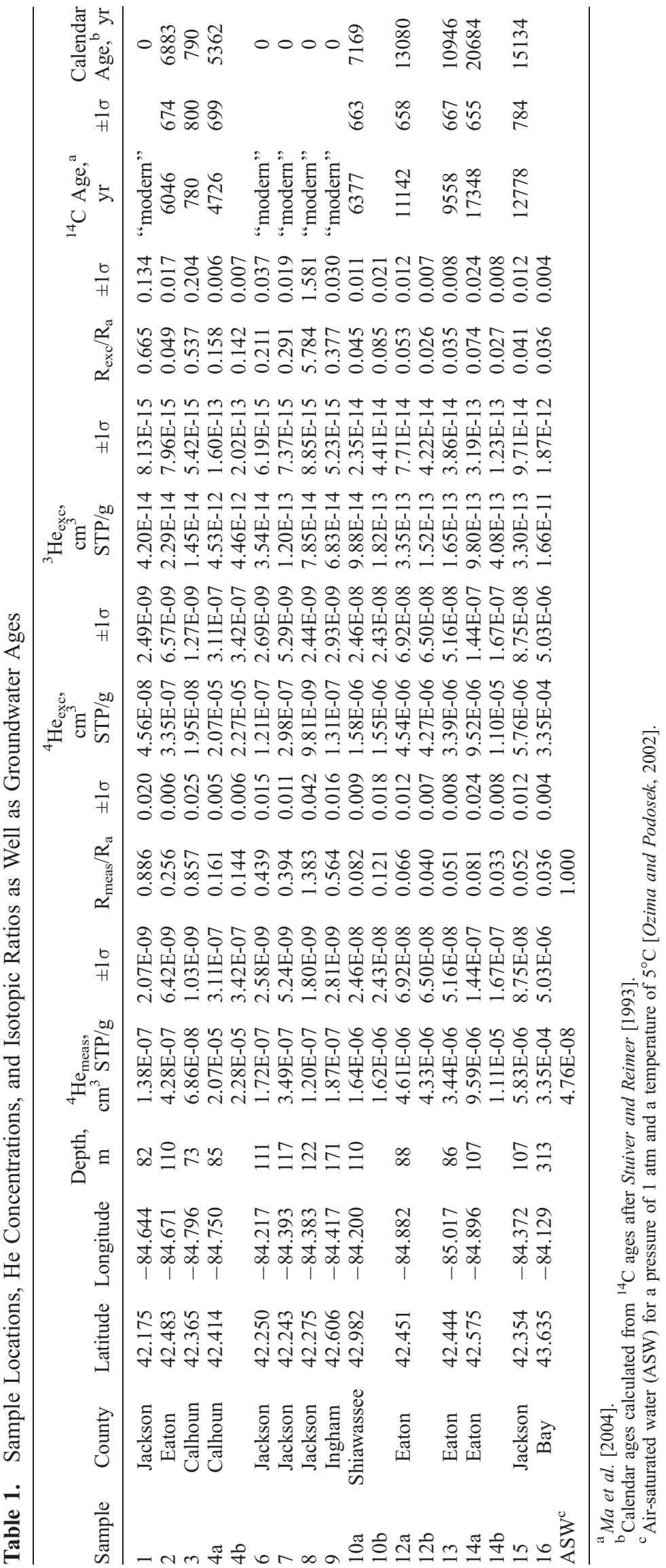


Table 2. Major Element Data for Samples From the Marshall Aquifer

\begin{tabular}{cccccccccccccc}
\hline Sample & $\mathrm{pH}$ & $\begin{array}{c}\mathrm{T}, \\
{ }^{\circ} \mathrm{C}\end{array}$ & $\begin{array}{c}\mathrm{TDS}, \\
\mathrm{mg} / \mathrm{L}\end{array}$ & $\begin{array}{c}\text { Alkalinity, } \\
\mathrm{meq} / \mathrm{kg}\end{array}$ & $\begin{array}{c}\mathrm{Cl}, \\
\mathrm{mM}\end{array}$ & $\begin{array}{c}\mathrm{Br}, \\
\mathrm{mM}\end{array}$ & $\begin{array}{c}\mathrm{SO}_{4}, \\
\mathrm{mM}\end{array}$ & $\begin{array}{c}\mathrm{Na}, \\
\mathrm{mM}\end{array}$ & $\begin{array}{c}\mathrm{Ca}, \\
\mathrm{mM}\end{array}$ & $\begin{array}{c}\mathrm{Mg}, \\
\mathrm{mM}\end{array}$ & $\begin{array}{c}\mathrm{K}, \\
\mathrm{mM}\end{array}$ & $\begin{array}{c}\mathrm{Sr}, \\
\mathrm{mM}\end{array}$ & $\begin{array}{c}\mathrm{CB},{ }^{\mathrm{a}} \\
\%\end{array}$ \\
\hline 1 & 7.0 & 11.3 & 541.0 & 5.914 & 0.496 & 0.0000 & 0.303 & 0.335 & 2.147 & 1.028 & 0.023 & 0.0014 & -2.2 \\
2 & 7.3 & 10.4 & 560.1 & 6.486 & 0.074 & 0.0000 & 0.245 & 0.812 & 1.688 & 1.208 & 0.238 & 0.0260 & -1.5 \\
4 & 7.0 & 9.8 & 1707 & 6.068 & 0.689 & 0.0000 & 7.579 & 2.489 & 8.895 & 1.332 & 0.698 & 0.1157 & 1.8 \\
6 & 7.7 & 11.1 & 499.7 & 5.386 & 0.462 & 0.0005 & 0.098 & 0.665 & 1.728 & 0.843 & 0.065 & 0.0258 & -1.0 \\
7 & 7.4 & 11.3 & 756.3 & 6.297 & 1.748 & 0.0018 & 1.008 & 2.140 & 2.747 & 1.243 & 0.074 & 0.0103 & 0.8 \\
8 & 7.1 & 11.7 & 789.5 & 7.113 & 1.021 & 0.0010 & 1.247 & 0.364 & 3.450 & 1.297 & 0.036 & 0.0021 & -3.6 \\
9 & 7.3 & 10.8 & 626.5 & 6.258 & 0.708 & 0.0000 & 0.620 & 0.717 & 2.385 & 1.297 & 0.076 & 0.0096 & -0.3 \\
10 & 7.7 & 11.8 & 958.2 & 6.435 & 1.418 & 0.0023 & 2.398 & 8.994 & 1.086 & 0.672 & 0.100 & 0.0324 & -0.2 \\
12 & 8.0 & 11.5 & 1062 & 6.861 & 2.692 & 0.0106 & 2.590 & 8.099 & 1.654 & 0.999 & 0.158 & 0.0208 & -4.2 \\
13 & 8.2 & 11.2 & 1020 & 6.863 & 5.797 & 0.0511 & 0.694 & 6.399 & 3.048 & 1.251 & 0.249 & 0.0436 & 3.9 \\
14 & 8.1 & 12.2 & 1530 & 5.128 & 15.21 & 0.0499 & 1.714 & 13.44 & 3.206 & 1.597 & 0.287 & 0.0551 & -1.0 \\
15 & 7.4 & 12.0 & 1376 & 7.646 & 8.600 & 0.0739 & 1.464 & 11.48 & 3.126 & 1.460 & 0.357 & 0.0531 & 4.4 \\
16 & 5.4 & 16.9 & 217105 & 0.286 & 4711 & 21.536 & 0.479 & 3164 & 708.4 & 310.2 & 19.10 & 7.2209 & 4.9 \\
\hline
\end{tabular}

\footnotetext{
${ }^{\mathrm{a}}$ Charge balance in \%.
}

[19] "Modern" water samples (1, 3, 6-9; see Table 1) [see discussion by $\mathrm{Ma}$ et al., 2004], i.e., samples at the proximity of recharge areas, display small $\mathrm{He}$ excesses $(<10$ times that of ASW; Figures $3 \mathrm{a}$ and $3 b$ ) and $0.21 \leq \mathrm{R}_{\mathrm{exc}} / \mathrm{R}_{\mathrm{a}} \leq 5.78$, the latter being far greater than typical crustal $\mathrm{He}$ values $(0.02-0.05)$. Thus these result either from natural or bomb ${ }^{3} \mathrm{H}$ decay or the addition of a mantle He component. Although no tritium measurements are available for our groundwater samples, tritium analysis performed in 1986 on one groundwater sample from the Marshall aquifer in our study area with similar ${ }^{14} \mathrm{C}$ activity and chemical composition to that of our young samples yielded 22TU [Dannemiller and Baltusis, 1990]. This value is well above the natural ${ }^{3} \mathrm{H}$ background in precipitations (usually $\leq 5$ TU [e.g., Roether, 1967]) and therefore indicates the addition of bomb test ${ }^{3} \mathrm{H}$ to this groundwater. Between 1963 (time of the bomb ${ }^{3} \mathrm{H}$ peak (e.g., International Atomic Energy Agency/World Meteorological Organisation, Global Network for Isotopes in Precipitation, Vienna, 1998)) and 1986, about two ${ }^{3} \mathrm{H}$ half lives have elapsed. A rough estimation was performed for the amount of ${ }^{3} \mathrm{H}$ that would be present in the recharge waters of this aquifer when the bomb tests reached their maximum. This simple calculation yields a value of $\sim 94 \mathrm{TU}$. Therefore between 1963 and 2003 (date of our sampling campaign), a maximum of $85 \mathrm{TU}$ have decayed into ${ }^{3} \mathrm{He}$ in these groundwaters, equivalent to the addition of $2.1 \times 10^{-13} \mathrm{~cm}^{3} \mathrm{STP} / \mathrm{g}{ }^{3} \mathrm{He}$ in water $\left(1 \mathrm{TU}=2.5 \times 10^{-15} \mathrm{~cm}^{3} \mathrm{STP} / \mathrm{g}{ }^{3} \mathrm{He}\right)$. This amount of anthropogenic ${ }^{3} \mathrm{He}$ is capable of explaining the ${ }^{3} \mathrm{He}$ excess observed in our young samples $\left({ }^{3}\right.$ He excess: $1.5 \times 10^{-14}$ to $1.2 \times 10^{-13} \mathrm{~cm}^{3} \mathrm{STP} / \mathrm{g}$ ).
Although we cannot be certain that most ${ }^{3} \mathrm{He}_{\text {exc }}$ in these samples result from bomb tritium decay due to water age uncertainties associated with these samples (see discussion by Ma et al. [2004]), the observed high $R_{\text {exc }} / R_{a}$ values associated with these young water ages strongly suggest that most ${ }^{3} \mathrm{He}_{\text {exc }}$ in these samples are the result of anthropogenic tritium decay. The simultaneous presence of a small amount of ${ }^{4} \mathrm{He}_{\text {exc }}$ indicates a mixture between this young water component and an older one. The observed decrease of $R_{\text {exc }} / R_{a}$ values with increased ${ }^{3} \mathrm{He}_{e x c}$ and ${ }^{4} \mathrm{He}_{\text {exc }}$ and increased groundwater ages further supports this hypothesis. The presence of a small mantle He component in these samples although less likely, cannot be excluded completely.

[20] With the exception of "modern" water samples as well as sample 4, all other samples (ages > 5 kyr; see Table 1 and Figures $3 \mathrm{a}$ and $3 \mathrm{~b}$ ) present lower $R_{\text {exc }} / R_{a}$ ratios, ranging from 0.09 (10b) to $0.03(12 b, 14 b)$, indicative of an increasing dominance of crustally produced ${ }^{3} \mathrm{He}$ and ${ }^{4} \mathrm{He}$ in these waters. Although most of these $\mathrm{R}_{\text {exc }} / \mathrm{R}_{\mathrm{a}}$ values fall into the typical crustally produced He values $(0.02 \leq$ $\mathrm{R}_{\mathrm{c}} / \mathrm{R}_{\mathrm{a}} \leq 0.05$ ), it is important to note that the presence of a significant mantle component that is potentially masked by dilution of the original signal by crustally produced $\mathrm{He}$ cannot be excluded (e.g., see discussion by Castro [2004]).

[21] As previously mentioned, samples 4a,b present an unusual He signature, with unusually high $\mathrm{He}$ excesses (approximately up to and above 2 orders of magnitude that of the ASW for ${ }^{3} \mathrm{He}$ and ${ }^{4} \mathrm{He}$, respectively) and high $\mathrm{R}_{\mathrm{exc}} / \mathrm{R}_{\mathrm{a}}$ values $(\sim 0.16)$ as compared to its groundwater age ( $\sim 5 \mathrm{kyr})$. In addition, and as discussed above, the amount of 
tritiogenic He that is potentially present is these waters is negligible with respect to its ${ }^{3} \mathrm{He}_{\text {exc }}$. Thus this high $R_{\text {exc }} / R_{a}$ value is clearly indicative of the presence of a mantle $\mathrm{He}$ component. If one assumes a simple binary mixture between a typical mantle component with $\mathrm{R}_{\mathrm{m}} / \mathrm{R}_{\mathrm{a}}=8$ and a crustal
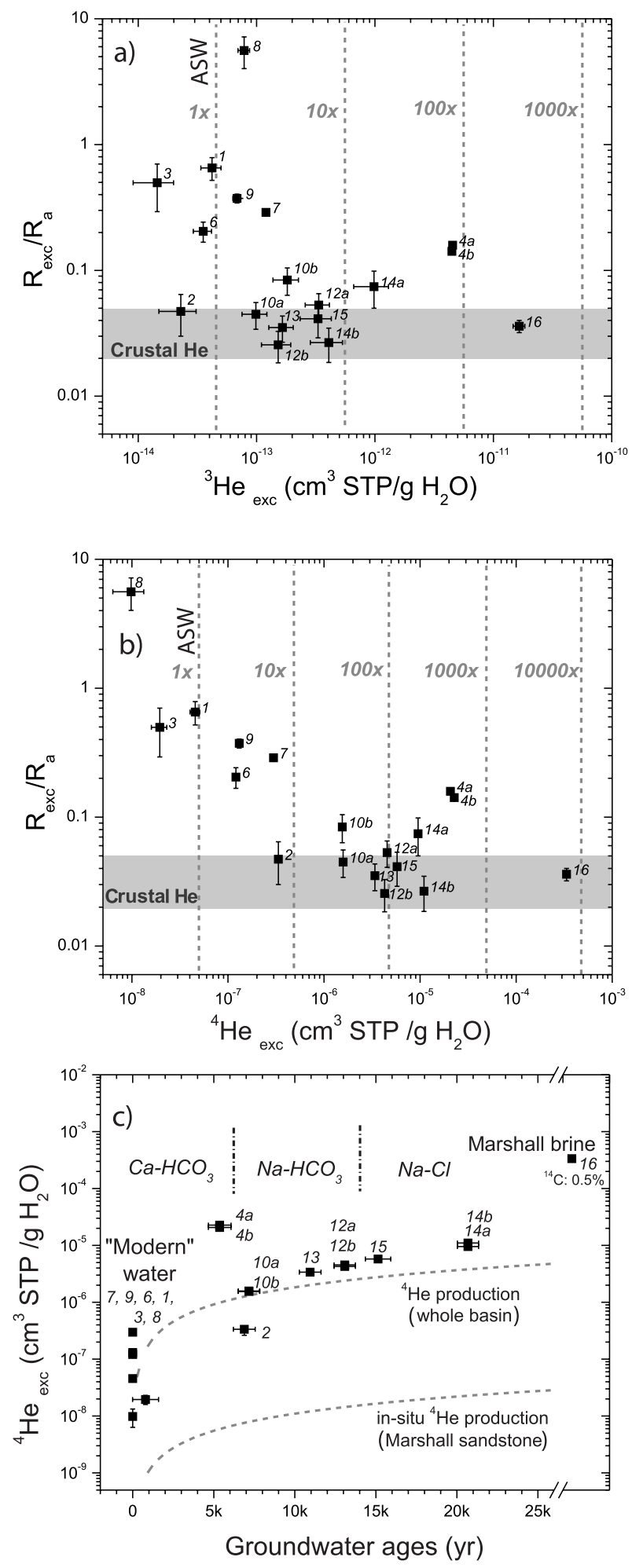

component with $\mathrm{R}_{\mathrm{c}} / \mathrm{R}_{\mathrm{a}}=0.02$, the corresponding mantle contribution is $\sim 2 \%$. Significant mantle $\mathrm{He}$ contributions in groundwaters are commonly found in active tectonic geological settings [e.g., Stute et al., 1992; Hilton et al., 2002; Saar et al., 2005]. However, mantle He signatures in groundwater from stable tectonic settings have also been documented [Torgersen et al., 1995; Siegel et al., 2004; Castro, 2004]. The mantle signature found in samples $4 \mathrm{a}, \mathrm{b}$ together with the observed high ${ }^{3} \mathrm{He}$ and ${ }^{4} \mathrm{He}$ excesses, strongly suggests a deeper origin for these water samples and the potential presence of a local deep permeable fault.

[22] On the basis of the $\mathrm{R}_{\text {exc }} / \mathrm{R}_{\mathrm{a}}$ values and ${ }^{3} \mathrm{He}_{\mathrm{exc}}$ values from the Marshall aquifer, it is clear that addition of tritiogenic ${ }^{3} \mathrm{He}$ can account for most of the observed ${ }^{3} \mathrm{He}$ excess in "modern" water samples, while older water samples are largely dominated by crustal (nucleogenic) ${ }^{3} \mathrm{He}$. A smaller mantle contribution is also present in at least some of the older samples.

\subsection{Crustal ${ }^{3} \mathrm{He}$ and ${ }^{4} \mathrm{He}$ Components: External Versus in Situ Production Origin}

[23] From the above discussion it is clear that with the exception of tritiogenic ${ }^{3} \mathrm{He}$ in young waters and the presence of a small mantle component in older samples, most of the excess ${ }^{3} \mathrm{He}$ and ${ }^{4} \mathrm{He}$ in the groundwaters of the Marshall aquifer is of crustal origin. Here, we discuss the origin of the crustally produced ${ }^{3} \mathrm{He}$ and ${ }^{4} \mathrm{He}$, in order to ascertain whether or not ${ }^{3} \mathrm{He}_{\text {exc }}$ and ${ }^{4} \mathrm{He}_{\text {exc }}$ present in the Marshall waters result mostly from in situ production within the aquifer, or if instead, it has an external deeper origin. With regard to the latter, it is also important to ascertain whether or not the

Figure 3. (a and b) $R_{e x c} / R_{a}$ values versus ${ }^{3} \mathrm{He}$ and ${ }^{4} \mathrm{He}$ excess concentrations for samples from the Marshall aquifer, respectively. Vertical dashed lines indicate $1 \times$, $10 \times, 100 \times, 1000 \times$ the ASW value at $1 \mathrm{~atm}$ pressure and $5^{\circ} \mathrm{C}$; shaded areas indicate typical crustal $R_{c} / R_{a}$ values $(0.02-0.05)$. (c) ${ }^{4} \mathrm{He}$ excess versus groundwater (calendar) ages. Dashed lines indicate He accumulation resulting both from in situ production in the Marshall sandstone and from the sedimentary sequence underlying the Marshall aquifer ("whole basin"), respectively; groundwater hydrochemical facies are also indicated. "Modern" water refers to samples for which the water age $\leq 1000$ years (Table 1) [see Ma et al., 2004]. Sample 16 corresponds to a Marshall brine sample with TDS $217 \mathrm{~g} / \mathrm{L}$ for which it was not possible to fit a ${ }^{14} \mathrm{C}$ model age due to its high salinities; $0.5 \%$ corresponds to the ${ }^{14} \mathrm{C}$ activity measured. 
Table 3. Calculated ${ }^{3} \mathrm{He}$ and ${ }^{4} \mathrm{He}$ Production Rates and Corresponding ${ }^{3} \mathrm{He} /{ }^{4} \mathrm{He}$ and $\mathrm{R}_{\mathrm{in}} / \mathrm{R}_{\mathrm{a}}$ Ratios in the Michigan Basin as Well as ${ }^{4} \mathrm{He}$ Production Rates in the Crystalline Basement

\begin{tabular}{|c|c|c|c|c|c|c|c|c|c|c|c|c|}
\hline Lithology & $\begin{array}{c}\text { Thickness, } \\
\text { m }\end{array}$ & $\begin{array}{c}\text { Porosity, } \\
\%\end{array}$ & $\begin{array}{l}\text { Th, } \\
\text { ppm }\end{array}$ & $\begin{array}{c}\mathrm{U}, \\
\mathrm{ppm}\end{array}$ & $\begin{array}{l}\mathrm{Li}, \\
\mathrm{ppm}\end{array}$ & $\begin{array}{l}\text { Density, }{ }^{\mathrm{d}} \\
\mathrm{g} \mathrm{cm}^{-3}\end{array}$ & $\begin{array}{c}\left.\mathrm{P}^{4} \mathrm{He}\right] \\
\mathrm{cm}^{3} \mathrm{STP} \\
\mathrm{g}_{\text {rock }}{ }^{-1} \\
\mathrm{yr}^{-1}\end{array}$ & $\begin{array}{c}\left.\mathrm{P}_{3}^{3} \mathrm{He}\right] \\
\mathrm{cm}^{3} \mathrm{STP} \\
\mathrm{g}_{\text {rock }}{ }^{-1} \\
\mathrm{yr}^{-1}\end{array}$ & ${ }^{3} \mathrm{He} /{ }^{4} \mathrm{He}$ & $\mathrm{R}_{\mathrm{in}} / \mathrm{R}_{\mathrm{a}}$ & $\begin{array}{c}\mathrm{P}\left[{ }^{4} \mathrm{He}\right] \\
\mathrm{cm}^{3} \mathrm{STP} \\
\mathrm{g}_{\mathrm{H} 2 \mathrm{O}}{ }^{-1} \\
\mathrm{yr}^{-1}\end{array}$ & $\begin{array}{c}\left.\mathrm{P}{ }^{3} \mathrm{He}\right] \\
\mathrm{cm}^{3} \text { STP } \\
\mathrm{g}_{\mathrm{H} 2 \mathrm{O}}{ }^{-1} \\
\mathrm{yr}^{-1}\end{array}$ \\
\hline $\begin{array}{l}\text { Marshall } \\
\text { sandstone }^{\mathrm{a}}\end{array}$ & 90 & 20 & 1.7 & 0.45 & 15 & 2.6 & 1.03E-13 & 7.73E-22 & 7.50E-09 & 0.005 & $1.07 \mathrm{E}-12$ & $8.04 \mathrm{E}-21$ \\
\hline $\begin{array}{l}\text { Sedimentary } \\
\text { sequence } \\
\text { underlying } \\
\text { Marshall }^{\mathrm{b}}\end{array}$ & 2400 & & 7.4 & 2.7 & 32 & 2.5 & $5.38 \mathrm{E}-13$ & $8.61 \mathrm{E}-21$ & $1.60 \mathrm{E}-08$ & 0.012 & $1.83 \mathrm{E}-10$ & $4.03 \mathrm{E}-18$ \\
\hline $\begin{array}{l}\text { Crystalline } \\
\text { basement }^{\mathrm{c}}\end{array}$ & & & 12 & 4 & & & $8.27 \mathrm{E}-13$ & & & & & \\
\hline
\end{tabular}

${ }^{\mathrm{a}} \mathrm{U}$, Th, and Li estimated from average lithological composition after Parker [1967]; thickness and porosity values after Westjohn and Weaver [1996].

${ }^{b}$ Based on average lithological composition: shale $(40 \%)$, limestone $(20 \%)$, dolomite $(20 \%)$, evaporites $(10 \%)$, and sandstone $(10 \%)$ after Speece et al., 1985]; values of U, Th, and Li estimated from average lithological composition after Parker [1967] and Tolstikhin et al. [1996].

${ }^{\mathrm{c}} \mathrm{U}$ and Th estimated from outcrop area for the crystalline basement [Menuge et al., 2002].

d Density of rocks estimated after Clark [1966].

sedimentary sequence underlying the Marshall is the main contributor or if the crystalline basement is providing most of the He present in the Marshall groundwaters.

[24] To answer to this question, production rates of ${ }^{3} \mathrm{He}$ and ${ }^{4} \mathrm{He}$ were calculated for the Marshall Sandstone, the sedimentary formations underlying the Marshall aquifer, as well as the crystalline basement as follows [e.g., Ballentine, 1991]:

$$
\begin{aligned}
P\left({ }^{3} \mathrm{He}\right)= & (6.035[\mathrm{U}]+1.434[\mathrm{Th}]) \times[\mathrm{Li}] \\
& \times 10^{-23} \mathrm{~cm}^{3} \mathrm{STP} \mathrm{g}_{\text {rock }}^{-1} \mathrm{yr}^{-1} \\
P\left({ }^{4} \mathrm{He}\right)= & 1.207 \times 10^{-13}[U]+2.867 \\
& \times 10^{-14}[\mathrm{Th}] \mathrm{cm}^{3} \mathrm{STP} \mathrm{g}_{\text {rock }}^{-1} \mathrm{yr}^{-1},
\end{aligned}
$$

where $[L i],[U]$, and $[T h]$ represent the $\mathrm{Li}, \mathrm{U}$, and Th concentrations (ppm), respectively (Table 3 ). The accumulation rate of $\mathrm{He}$ isotopes in the water was then estimated according to the expression

$$
\begin{aligned}
{\left[P_{\mathrm{He}}^{i}\right]_{\mathrm{H}_{2} \mathrm{O}}=} & P\left({ }^{i} \mathrm{He}\right) \times \rho_{r} \times \Lambda \times((1-\omega) / \omega) \\
& \times \rho_{w} \mathrm{~cm}^{3} \mathrm{STP}_{\mathrm{H} 2 \mathrm{O}}^{-1} \mathrm{yr}^{-1},
\end{aligned}
$$

where $i$ represents ${ }^{3} \mathrm{He}$ or ${ }^{4} \mathrm{He}, \rho_{r}$ is the mass density of the rock in $\mathrm{gcm}^{-3}, \rho_{w}$ is the density of the water in $\mathrm{gcm}^{-3}, \omega$ is the porosity of the reservoir rock and $\Lambda$ is the transfer efficiency of $\mathrm{He}$ from the rock matrix to the water. For sediments, it can be assumed that $\Lambda=1$ [e.g., Torgersen, 1980; Torgersen and Clarke, 1985]. Table 3 lists the calculated ${ }^{3} \mathrm{He}$ and ${ }^{4} \mathrm{He}$ in situ production rates, thickness and porosity values for the Marshall aquifer, and the whole sedimentary sequence underlying the Marshall in the study area. Corresponding $\mathrm{R} / \mathrm{R}_{\mathrm{a}}$ production values as well as ${ }^{3} \mathrm{He}$ and ${ }^{4} \mathrm{He}$ accumulation rates in the water for the Marshall and underlying sedimentary sequences are also indicated. ${ }^{4} \mathrm{He}$ production rates for the crystalline basement are also given.

[25] If it is assumed that all ${ }^{3} \mathrm{He}$ and ${ }^{4} \mathrm{He}$ excesses in the Marshall groundwaters results from in situ production and if one excludes all "modern" samples, under such accumulation rates (Table 3) it would take between 2.3 and $1700 \mathrm{Myr}$, and 0.2 and $300 \mathrm{Myr}$ to produce the observed ${ }^{3} \mathrm{He}_{\text {exc }}$ and ${ }^{4} \mathrm{He}_{\text {exc }}$, time periods that would correspond to the required age of these groundwaters. Such groundwater ages seem to be far too high for most samples, and are clearly in contradiction with estimated ${ }^{14} \mathrm{C}$ ages (Table 1 ). In addition, the accumulation time required for the observed ${ }^{3} \mathrm{He}_{\text {exc }}$ in sample $16(1700 \mathrm{Myr})$ is far greater than the age of the Marshall Sandstone itself, clearly indicating that most of the excess $\mathrm{He}$ has an external origin to the aquifer. Similarly, the contrast between $R_{\text {exc }} / R_{a}$ ratios in the Marshall aquifer $(0.03-0.15)$ for samples with water ages $\geq 5 \mathrm{kyr}$ and that of in situ produced ratios (0.005) strongly suggests that $\mathrm{He}$ excesses in the Marshall aquifer have an external origin, with potentially some mantle contribution [e.g., see Castro, 2004]. Taking into account groundwater ages as well as in situ production rates, the expected $\mathrm{He}$ accumulation in the water 
resulting solely from in situ production within this sandstone aquifer is $\sim 2-3$ orders of magnitude lower than the observed excess He (Figure 3c). We thus conclude that in situ production is a negligible He source in the Marshall sandstone as compared to an external contribution. Such external $\mathrm{He}$ sources to aquifers have been documented in a diversity of sedimentary basins around the world [e.g., Torgersen and Clarke, 1985; Stute et al., 1992; Castro et al., 1998a, 1998b, 2000; Castro, 2004]. The occurrence of an external He flux has been widely accepted as the main He excess source in multilayered aquifer systems. Alternatively, Solomon et al. [1996] have proposed that diffusion of inherited ${ }^{4} \mathrm{He}$ could become the dominant external He source under specific conditions (e.g., shallow aquifers with high water velocities). Such conditions, however, do not apply to our system.

[26] External sources can be provided either by the underlying sedimentary sequence or by the crystalline basement, or both. We now attempt at quantifying these. The whole sedimentary sequence underneath the study area is $\sim 2.4 \mathrm{~km}$ thick and contains mainly carbonates, shales, sandstones, and evaporites [e.g., Fisher et al., 1988; Speece et al., 1985]. Taking into account these different lithological compositions, thickness, and respective production rates, we estimate that the entire sedimentary sequence is capable of producing $\sim 20$ and $\sim 50 \%$ of ${ }^{3} \mathrm{He}_{\text {exc }}$ and ${ }^{4} \mathrm{He}_{\text {exc }}$ in the Marshall aquifer (Figure 3c), respectively, if one excludes "modern" samples as well as sample 4. Indeed, production within the sedimentary sequence remains negligible for the latter $\left(0.5\right.$ and $4 \%$ for ${ }^{3} \mathrm{He}_{\text {exc }}$ and ${ }^{4} \mathrm{He}_{\text {exc }}$, respectively). The estimated contributions represent maximum bounds with respect to the observed $\mathrm{He}$ excesses. Thus, while ${ }^{3} \mathrm{He}$ production within the sedimentary sequence is a relatively marginal source for ${ }^{3} \mathrm{He}$ in the Marshall $(\leq 20 \%)$, production of ${ }^{4} \mathrm{He}$ within the basin underlying the Marshall has the potential to account for a non-negligible amount $(\leq 50 \%)$ of the total observed ${ }^{4} \mathrm{He}_{\text {exc }}$ in this aquifer.

[27] From the above discussion it is clear that an external source dominates both, ${ }^{3} \mathrm{He}_{\text {exc }}$ and ${ }^{4} \mathrm{He} e_{\text {exc }}$ in the Marshall aquifer. While the sedimentary sequence underlying the Marshall aquifer has the potential to play an important role at providing ${ }^{4} \mathrm{He}$ concentrations, most of the ${ }^{3} \mathrm{He}_{\text {exc }}$ appears to have its source in the crystalline basement. In the following section, we estimate the external vertical ${ }^{3} \mathrm{He}$ and ${ }^{4} \mathrm{He}$ fluxes entering the Marshall aquifer from the combined underlying sedimentary se- quence and crystalline basement, and attempt at better constraining the He provided by each one of these sources.

\subsection{He Transport Simulations: Estimation of ${ }^{3} \mathrm{He}$ and ${ }^{4} \mathrm{He}$ External Fluxes}

\subsubsection{Conceptual Model}

[28] In order to quantify the transfer of $\mathrm{He}$ to, and its accumulation in, a confined aquifer, Torgersen and Ivey [1985] proposed a simple model assuming that steady state for flow and transport is reached in the system. Here, we adopt a similar procedure to quantify the ${ }^{3} \mathrm{He}$ and ${ }^{4} \mathrm{He}$ upward fluxes entering the bottom of the Marshall aquifer. The advectiondispersion equation governing the model is given by

$$
v_{x} \frac{\partial C}{\partial x}+D_{T} \frac{\partial^{2} C}{\partial z^{2}}=P
$$

where $v_{x}$ is the advective pore velocity in the $x$ (horizontal) direction, $x$ is the distance from the recharge area of the aquifer, $z$ is the relative vertical position inside the aquifer, $C$ corresponds to the ${ }^{3} H e_{e x c}$ or ${ }^{4} H e_{e x c}$ concentrations, $D_{T}$ is the coefficient of hydrodynamic transverse dispersion given by $D_{T}=\alpha_{z} v_{x}+d$ [see, e.g., Freeze and Cherry, 1979]. Thus it includes both vertical dispersion expressed as a function of transverse dispersivity $\left(\alpha_{z}\right)$ and diffusion expressed by the molecular diffusion coefficient for the solute in the porous medium $d . P$ is a source term and in our case it represents the accumulation of ${ }^{3} \mathrm{He}$ and ${ }^{4} \mathrm{He}$ in the water resulting from in situ production, as calculated from equation (6). The prescribed boundary conditions for this model are (1) a ${ }^{3} \mathrm{He}$ or ${ }^{4} \mathrm{He}$ concentration that initially is zero for all depths in the aquifer; (2) a flux $J_{0}$ of ${ }^{3} \mathrm{He}$ or ${ }^{4} \mathrm{He}$ entering the aquifer across the bottom boundary $z_{0}$, assumed to be constant; (3) a no-flux ${ }^{3} \mathrm{He}$ and ${ }^{4} \mathrm{He}$ boundary condition at the top of the aquifer, i.e., no He losses occurring through the top of the aquifer are allowed. He studies in multilayered aquifer systems in which the advective, dispersive and diffusive fluxes were quantified [see Castro et al., 1998b] show a very important reduction of these losses of up to 30 times the (total vertical flux) flux $J_{0}$ entering at the bottom of the aquifer. In view of such results, the prescribed zero He flux boundary condition at the top of the aquifer seems to be reasonable as compared to the $J_{0}$ flux entering the bottom of the aquifer [see also Castro et al., 2000]. 
[29] The analytical solution to this problem is given by [Torgersen and Ivey, 1985]

$$
\begin{aligned}
C= & P t+\frac{J_{0} t}{z_{0} \rho \omega}+\frac{J_{0} z_{0}}{D_{T} \rho \omega}\left[\frac{3\left(\frac{z}{z_{0}}\right)^{2}-1}{6}-\frac{2}{\pi^{2}} \sum_{m=1}^{\infty} \frac{(-1)^{m}}{m^{2}}\right. \\
& \left.\cdot \exp \left(-\frac{D_{T} m^{2} \pi^{2} t}{z_{0}^{2}}\right) \cos \left(\frac{m \pi z}{z_{0}}\right)\right],
\end{aligned}
$$

where $z_{0}$ is the thickness of the aquifer $(\mathrm{m}), \rho$ is the water density $\left(1 \mathrm{gcm}^{-3}\right), \omega$ is the porosity, $J_{0}$ is the upward ${ }^{3} \mathrm{He}$ or ${ }^{4} \mathrm{He}$ flux $\left(\mathrm{cm}^{3}\right.$ STP $\left.\mathrm{cm}^{-2} \mathrm{yr}^{-1}\right)$ entering the bottom of the confined aquifer, and $t$ is the groundwater age (yr). Because an exact recharge distance $(x)$ for all samples is difficult to estimate due to the concentric shape of the Marshall subcrop (Figure 2), excess He concentrations $(C)$ were calculated and are presented as a function of groundwater ages $(t)$ (Table 1).

[30] This analytical model was calibrated for an average thickness of the Marshall aquifer in the study area of $\sim 90 \mathrm{~m}$, and a constant value of $D_{T}=$ $0.13 \mathrm{~m}^{2} \mathrm{yr}^{-1}$ chosen on the basis of measurements of transverse dispersion performed in a homogeneous sandstone at various flow rates $(0.32$ to $16 \mathrm{~m}$ $\mathrm{yr}^{-1}$ [Freeze and Cherry, 1979; see also Castro et al., 2000]). In situ production accumulation rates $(P)$ in the Marshall aquifer for ${ }^{3} \mathrm{He}$ and ${ }^{4} \mathrm{He}$ are

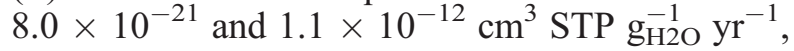
respectively (Table 3 ).

[31] Except for sample 16 for which no groundwater age is available as it was not possible to fit a ${ }^{14} \mathrm{C}$ model age for a fluid with such high salinities, all other samples were used for calibration of the transport model.

\subsubsection{Results and Discussion}

[32] Figures $4 \mathrm{a}$ and $4 \mathrm{~b}$ show the calculated ${ }^{3} \mathrm{He}_{\text {exc }}$ and ${ }^{4} \mathrm{He}_{\text {exc }}$ from the bottom $\left(z / z_{0}=1\right)$ to the top of the aquifer $\left(z / z_{0}=0\right)$ at constant intervals of $0.2\left(z / z_{0}\right)$ (plain lines) as a function of the groundwater ages for our calibrated model. Contributions of ${ }^{3} \mathrm{He}$ and ${ }^{4} \mathrm{He}$ in situ accumulation in the water are also shown (dashed lines). Calculated ${ }^{3} \mathrm{He}_{\text {exc }}$ and ${ }^{4} \mathrm{He}_{\text {exc }}$ concentrations increase with increased groundwater ages as well as with increased relative depth $\left(z / z_{0}\right)$. Most of our samples with groundwater ages $\geq 5 \mathrm{kyr}$ are located in the upper portion of the aquifer $\left(z / z_{0} \leq\right.$ 0.4 ) and it is apparent that, except for sample 4, our calibrated model reproduces reasonably well the observed $\mathrm{He}$ excesses. The best fit obtained indicates that the high ${ }^{3} \mathrm{He}_{\text {exc }}$ and ${ }^{4} \mathrm{He} e_{\text {exc }}$ observed in the Marshall aquifer require He flux values of $1 \times 10^{-13}$ and $1.6 \times 10^{-6} \mathrm{~cm}^{3} \mathrm{STP} \mathrm{cm}^{-2} \mathrm{yr}^{-1}$ for ${ }^{3} \mathrm{He}$ and ${ }^{4} \mathrm{He}$, respectively (Figures $4 \mathrm{a}$ and $4 \mathrm{~b}$ ). Estimated $\mathrm{He}$ fluxes yield a $R_{\text {exc }} / R_{a}=0.045$ entering the bottom of the aquifer, a value that is consistent with the observed average $R_{\text {exc }} / R_{a}$ value of 0.047 of all samples with groundwater ages $\geq 5 \mathrm{kyr}$, with the exception of sample 4. The model also indicates, as previously concluded (section 5.3) that in situ production from the Marshall sandstone is negligible, yielding concentrations that are $\sim 2-3$ orders of magnitude lower than the observed excess $\mathrm{He}$ in the Marshall aquifer (dashed lines, Figures 4a and $4 \mathrm{~b})$.

[33] Although these fluxes should be taken as a first order approximation due to the simplifications implemented in the model, it is clear that He fluxes entering the Marshall aquifer are far greater than He fluxes reported in other sedimentary basins at similar $(\leq 300 \mathrm{~m})$, and far greater depths (Figure 5). For example, the upward ${ }^{4} \mathrm{He}$ flux entering the Marshall aquifer is over an order of magnitude greater than the one entering the Carrizo aquifer (46 times, average depth $1000 \mathrm{~m}$ [cf. Castro and Goblet, 2003]) in the Gulf Coast Basin, and presents an intermediate value between fluxes entering the Albian (depth $\sim 800 \mathrm{~m}$ ) and Lusitanian aquifers (depth $\sim 1600 \mathrm{~m}$ ) at the center of the Paris Basin [Castro et al., 1998b]. This flux is also significantly higher than those estimated in the Great Hungarian Plain [Stute et al., 1992], and close to that estimated in the Great Artesian Basin [Torgersen and Ivey, 1985]. A similar pattern is observed for ${ }^{3} \mathrm{He}$ fluxes. Such high He fluxes present at such shallow depths within the Michigan Basin strongly suggest the existence of a deep groundwater flow system in place distinct from many other multilayered sedimentary systems around the world, in which an horizontal component of groundwater flow plays an important role. Indeed, Castro et al. [1998b] have shown that ${ }^{4} \mathrm{He}$ fluxes decrease rapidly toward the surface (e.g., see Figure 5) as a result of a progressive dilution by recharge water carrying a small atmospheric $\mathrm{He}$ component present in deeper aquifers/formations. Such steep flux decrease does not appear to be present in the Michigan Basin, suggesting that the impact of the horizontal flow component (e.g., recharge water) at depth is minor. The presence of a dominant vertical flow component (upward leakage) with respect to a horizontal one is also likely responsible for the extremely high salinities in the shallow subsurface of the Michigan Basin. 

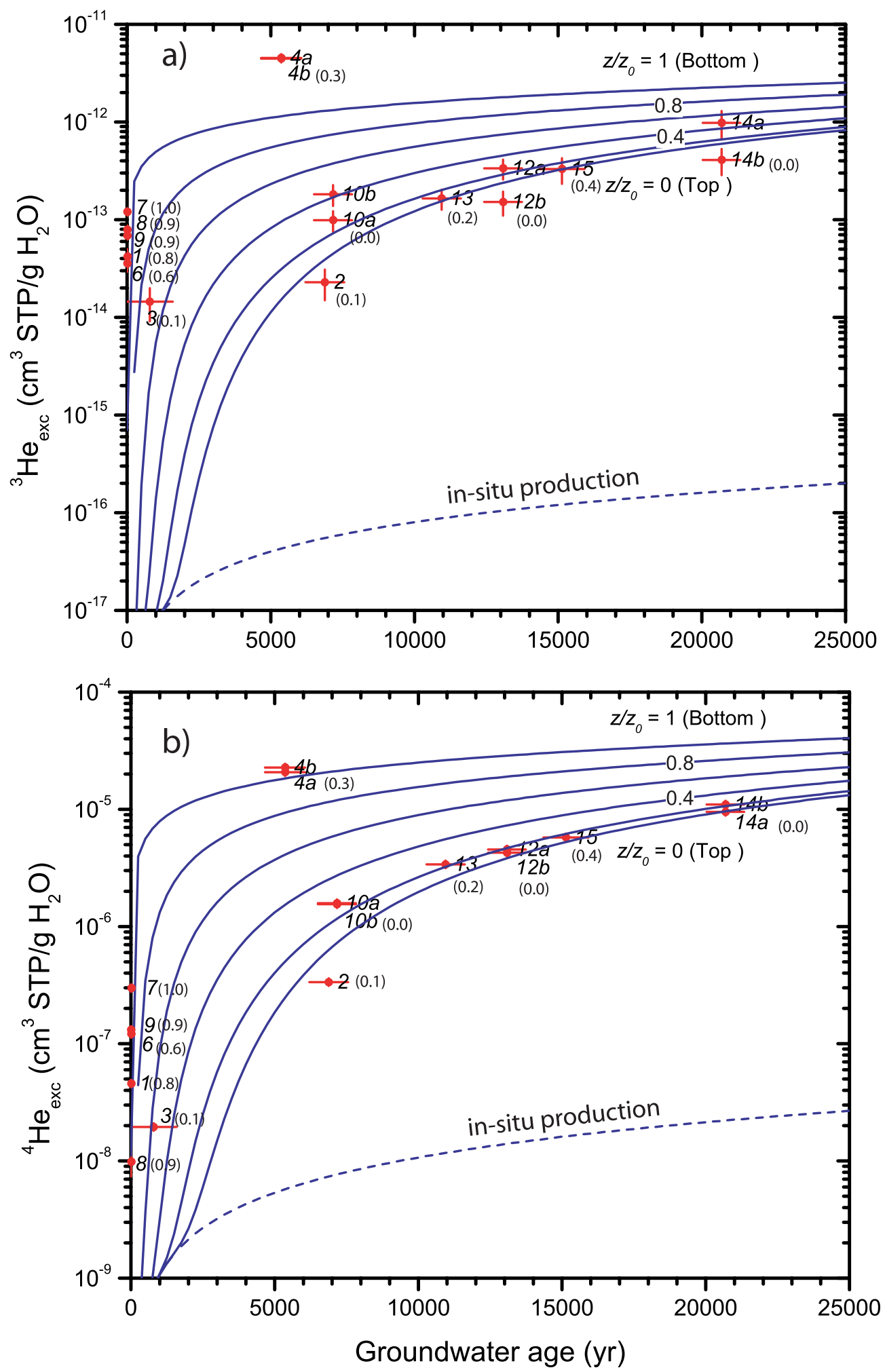

Figure 4. ( $\mathrm{a}$ and b) Calculated ${ }^{3} \mathrm{He}_{\mathrm{exc}}$ and ${ }^{4} \mathrm{He}_{\mathrm{exc}}$ concentration curves from the bottom $\left(z / z_{0}=1\right)$ to the top of the aquifer $\left(z / z_{0}=0\right)$ at constant intervals of $0.2\left(z / z_{0}\right)$ as a function of the groundwater (calendar) ages for the calibrated model in the Marshall aquifer, respectively. ${ }^{3} \mathrm{He}_{\mathrm{exc}}$ and ${ }^{4} \mathrm{He}_{\text {exc }}$ values are also shown as well as the calculated ${ }^{3} \mathrm{He}_{\text {exc }}$ and ${ }^{4} \mathrm{He}_{\mathrm{exc}}$ concentration curves resulting from in situ production alone (dashed line). Relative depths $\left(z / z_{0}\right)$ are indicated for all wells. 


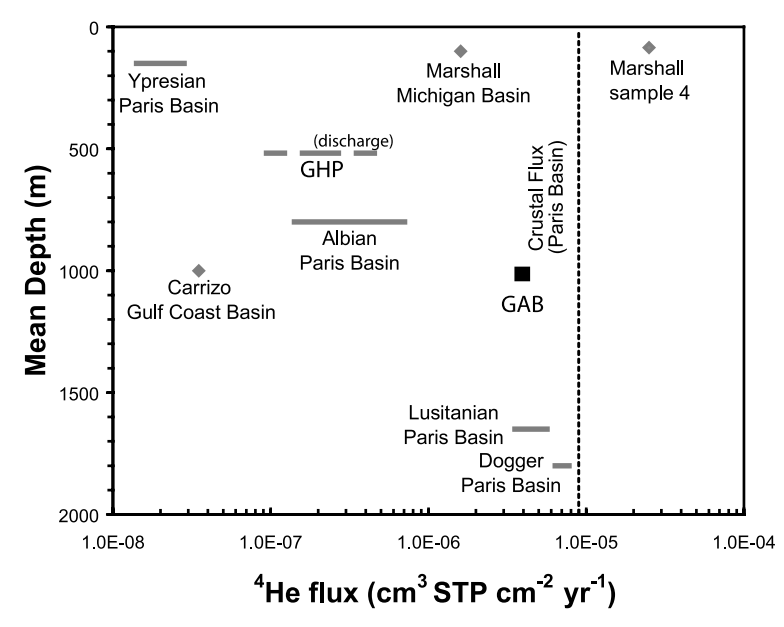

Figure 5. Estimated ${ }^{4} \mathrm{He}$ fluxes entering the Marshall aquifer as compared to ${ }^{4} \mathrm{He}$ fluxes entering aquifers in other multilayered sedimentary basins: the Carrizo aquifer in the Gulf Coast Basin [Castro and Goblet, 2003], the Ypresian, Albian, Lusitanian, and Dogger aquifers in the central portion of the Paris Basin [Castro et al., 1998b], and the Great Artesian Basin [Torgersen and Ivey, 1985]. Although not a multilayered system, ${ }^{4} \mathrm{He}$ fluxes estimated in the Great Hungarian Plain [Stute et al., 1992] are also indicated for comparison; the crustal flux entering the Paris Basin is also indicated [Castro et al., 1998b].

[34] On the basis of measured U and Th concentrations in the Precambrian crystalline basement of our study area (Table 3), we estimate that, in addition to production within the sedimentary sequence $(\sim 2.4 \mathrm{~km})$, at least $\sim 6 \mathrm{~km}$ of crystalline basement would be required to produce the ${ }^{4} \mathrm{He}$ flux underneath the Marshall aquifer. This rough estimation indicates that about $20 \%$ of ${ }^{4} \mathrm{He}_{\text {exc }}$ in the Marshall could result from the sedimentary sequence, while $\sim 80 \%$ might originate in the basement. Li concentrations are not available for the Precambrian crystalline basement; thus we cannot make such estimations for ${ }^{3} \mathrm{He}_{\text {exc }}$. However, as previously discussed, it is expected that the crystalline basement is by far the most important source of ${ }^{3} \mathrm{He}_{\text {exc }}$ observed in the Marshall. The basement underneath the study area is highly fractured (Figure 1a) and it is likely that the presence of faults act as conduits for groundwater flow, thereby enhancing vertical He transport within the crystalline basement, at great depths.

[35] Such high fluxes entering the Marshall aquifer cannot, however, explain the high ${ }^{3} \mathrm{He}_{\text {exc }}$ and ${ }^{4} \mathrm{He}_{e x c}$ observed in samples $4 \mathrm{a}, \mathrm{b}$, which were collected from the upper portion of the aquifer $\left(z / z_{0}=0.3\right)$. In order to fit such He excesses, fluxes of $5 \times 10^{-12}$ and $2 \times 10^{-5} \mathrm{~cm}^{3}$ STP cm $\mathrm{cm}^{-2} \mathrm{yr}^{-1}$, for ${ }^{3} \mathrm{He}_{\text {exc }}$ and ${ }^{4} \mathrm{He}_{\text {exc }}$ are required, respectively. These yield $\mathrm{R}_{\text {exc }} / \mathrm{R}_{\mathrm{a}} \sim 0.18$, a value that is consistent with our observed $R_{\text {exc }} / R_{a}$ of 0.15 (average for samples $4 a, b)$, strongly suggesting the presence of a more significant and local mantle component in this area. Comparison between ${ }^{4} \mathrm{He}$ flux values required to fit samples $4 a, b$ and the crustal flux value determined underneath the Paris Basin (Figure 5) further supports the notion that a mantle flux is partly responsible for the total local He flux in this area.

[36] Overall, our results indicate that $\mathrm{He}$ has an origin external to the aquifer, from deeper sources, strongly supporting the presence of cross-formational flow (upward leakage) throughout most of the sedimentary sequence within the Michigan Basin. Our results also suggest that the impact of a horizontal flow component (e.g., recharge water) at depth is minor. This dominant vertical water component with respect to the horizontal one can explain the observed major ions vertical patterns within the Michigan Basin as well as the extremely high salinities observed at the shallow subsurface. We analyze these below.

\section{Origin of High Salinity in the Shallow Subsurface of the Michigan Basin}

[37] In a similar manner to the observed unusually high $\mathrm{He}$ excesses, high salinity values have been widely documented in both aquifers and aquitards at the shallow subsurface in the Michigan Basin [e.g., Long et al., 1988; Weaver et al., 1995; Ging et al., 1996]. The origin of solutes in these shallow groundwaters remains uncertain and upward transport of underlying basinal brines into shallow depths and subsequent mixing with recently recharged meteoric water has been suggested to explain the observed salinity distributions [Long et al., 1988; Ging et al., 1996; Weaver et al., 1995; Kolak et al., 1999]. Our results presented above clearly indicate that the main source of $\mathrm{He}$ in the Marshal is external to the aquifer, partly from the underlying sedimentary sequence, partly from the crystalline basement, and strongly support the presence of large scale cross-formational flow within the Michigan Basin.

[38] If our hypothesis based on He isotopes is correct and upward leakage indeed occurs throughout most of the sedimentary sequence, its vertical impact on major ion chemistry evolution should be equally and clearly observed. Thus we now analyze the major ion chemistry systematics not only 

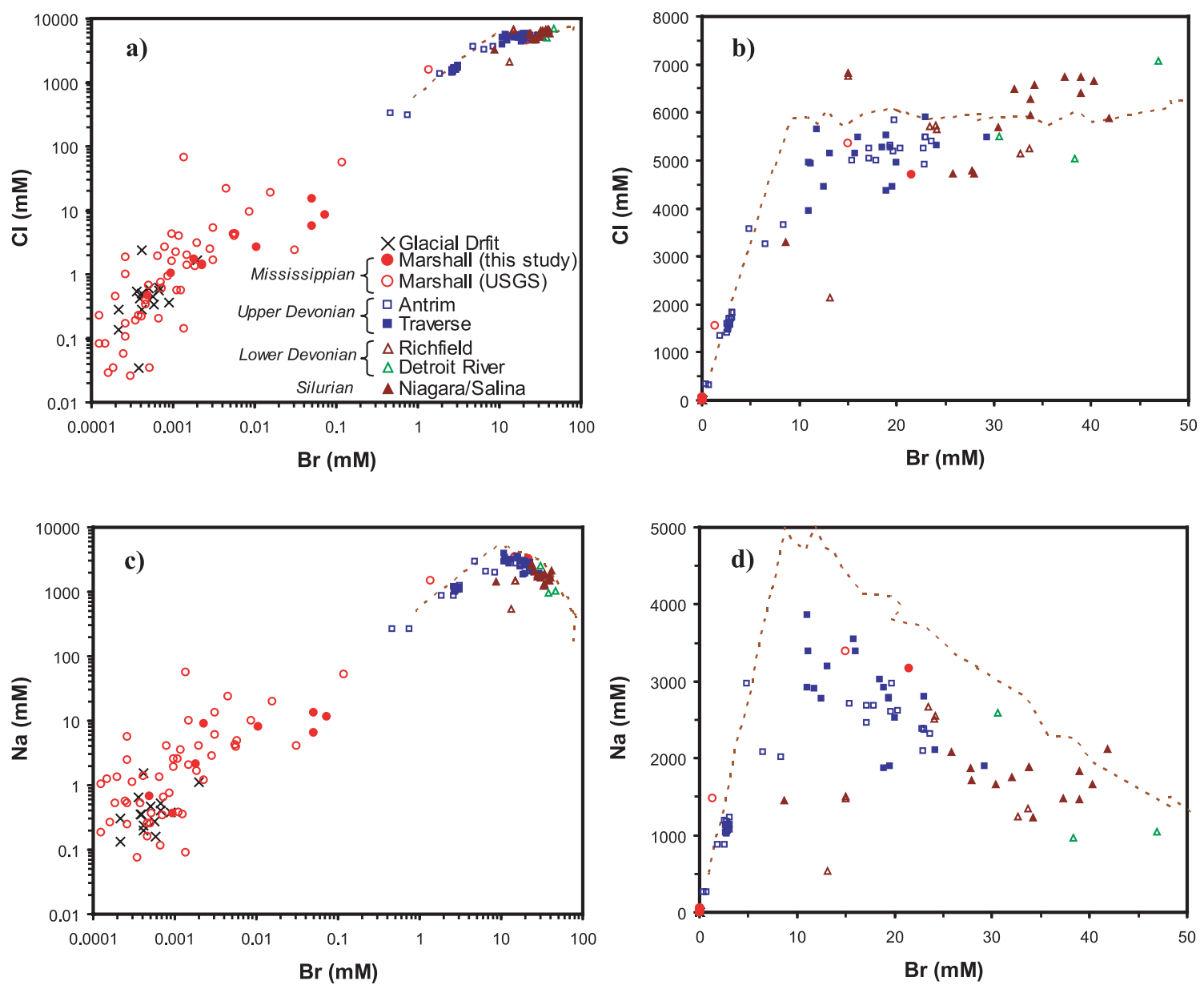

Figure 6. $\mathrm{Cl}^{-}$and $\mathrm{Na}^{+}$versus $\mathrm{Br}^{-}$concentrations, respectively, for the Marshall aquifer (closed red circles, this study; open red circles, Dannemiller and Baltusis [1990]), the Glacial Drift (black crosses, Dannemiller and Baltusis [1990]), the Antrim Shale formation (open blue squares, McIntosh et al. [2004]), the Traverse formation (closed blue squares), the Richfield (open brown triangles), the Detroit River Group (open green triangles), and the Niagara/Salina formation (closed brown triangles) [Wilson and Long, 1993a, 1993b]. Both (a and c) log-log and (b and d) linear scales are shown; seawater-evaporation curves from McCaffrey et al. [1987] are also shown (brown dashed line).

within the Marshall aquifer, but rather, from the deeper Silurian up to the shallowest subsurface levels (Glacial Drift sediments; Figure 1c).

\subsection{General Data Overview}

[39] Because bromide remains in solution during seawater evaporation and is not modified by diagenetic processes [e.g., Carpenter, 1978; Stueber and Walter, 1991], in a similar manner to $\mathrm{He}, \mathrm{Br}^{-}$ behaves as a conservative tracer. Thus the latter is also an ideal element to trace groundwater circulation and to identify the origin of solutes. Consequently, in order to discuss the chemistry evolution within the Michigan Basin, all other ions are plotted as a function of $\mathrm{Br}^{-}$concentrations.
[40] Figures 6 and 7 show the concentrations of $\mathrm{Cl}^{-}, \mathrm{Na}^{+}$, as well as $\mathrm{Ca}^{2+}, \mathrm{Mg}^{2+}, \mathrm{Sr}^{2+}$, and $\mathrm{K}^{+}$ plotted as a function of $\mathrm{Br}^{-}$, respectively, for the Marshall aquifer in southern Michigan (this study; Dannemiller and Baltusis [1990]), the overlying Glacial Drift [Dannemiller and Baltusis, 1990], the underlying Upper-Devonian Antrim shale [McIntosh et al., 2004] and Traverse carbonate formations [Wilson and Long, 1993b], as well as the evaporite-carbonate Lower-Devonian and Silurian formations [Wilson and Long, 1993a]. Results indicate that major ion concentrations vary between $4\left(\mathrm{Mg}^{2+}\right.$ and $\left.\mathrm{Ca}^{2+}\right)$ and $6\left(\mathrm{Br}^{-}, \mathrm{Cl}^{-}, \mathrm{Na}^{+}\right.$, and $\mathrm{Sr}^{2+}$ ) orders of magnitude from shallow fresh groundwater to deep brines in the Michigan Basin. $\mathrm{K}^{+}$concentrations display an intermediate variation, 

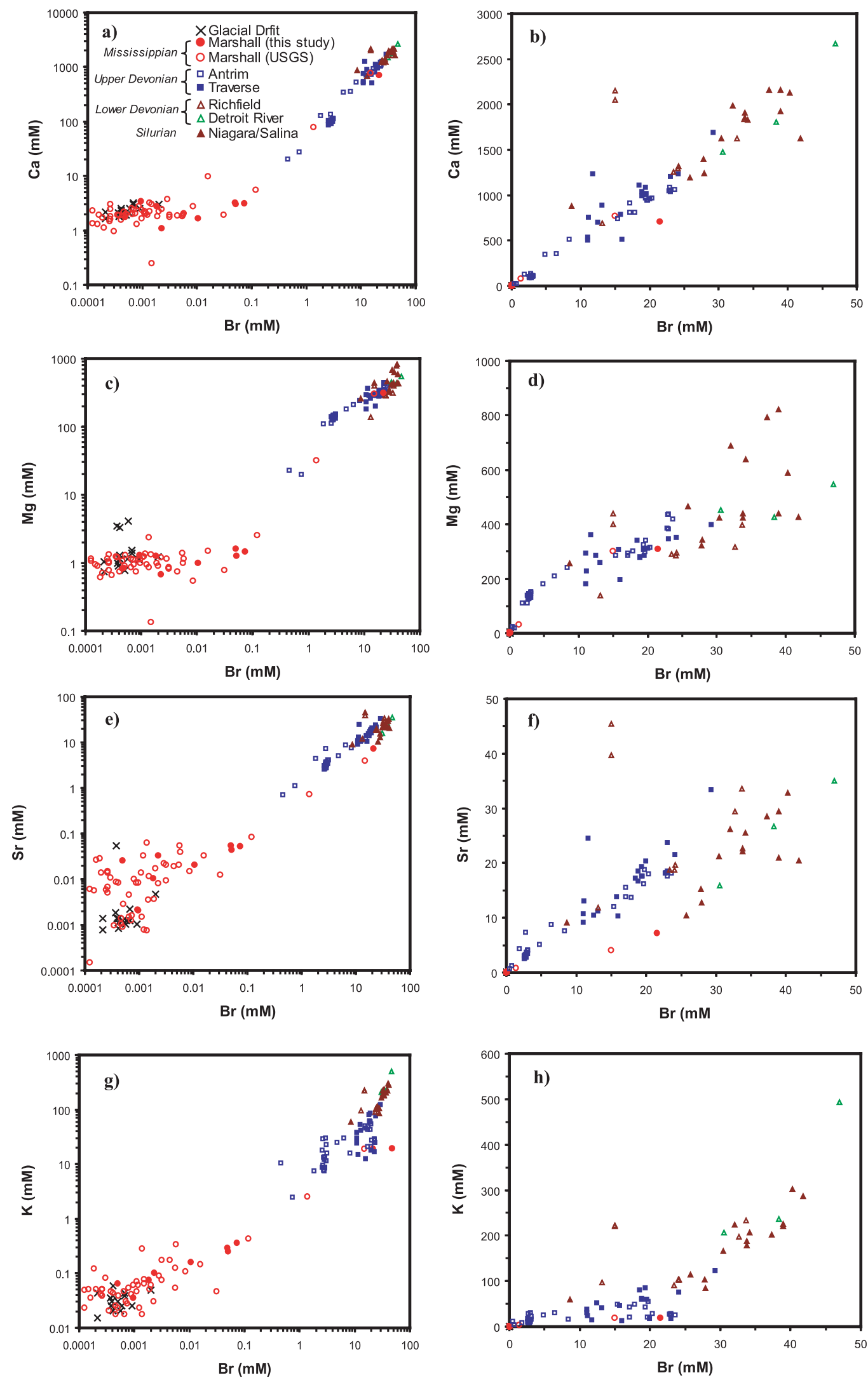

Figure 7 
up to 5 orders of magnitude. Due to these high variations in concentrations, element relationship plots are presented both in log-log and linear scale to allow for a detailed analysis of these distinct chemistry waters (Figures 6 and 7).

[41] In the sections that follow we first discuss the origin of salinity at the shallower levels, i.e., Glacial Drift through Traverse Formation (section 6.2). We then proceed to discuss how these shallower brines relate to those of deeper formations (Traverse-Silurian, section 6.3), and present then a brief overview of the observed vertical facies evolution and $\mathrm{He}-\mathrm{Br}^{-}$positive correlation (section 6.4).

\subsection{Origin of Salinities in the Shallow Subsurface of the Michigan Basin}

[42] Groundwater samples from the Marshall aquifer yield variable $\mathrm{Cl}^{-}$and $\mathrm{Br}^{-}$concentrations and display a positive correlation between these two elements (Figure 6a). Low $\mathrm{Cl}^{-}$and $\mathrm{Br}^{-}$concentrations are found close to the recharge area and are indistinguishable to the composition of fresh water in the overlying Glacial Drift. By contrast, samples close to the discharge area display high $\mathrm{Cl}^{-}$and $\mathrm{Br}^{-}$concentrations, with a signature similar to those of the most diluted underlying Antrim Formation brines (Figures 6a and 6b). While dissolution of evaporites in neighboring formations may explain some of the high $\mathrm{Cl}^{-}$concentrations observed locally in Antrim formation waters in the northern marginal basin [McIntosh et al., 2004], such a process, however, cannot account for the high $\mathrm{Br}^{-}$concentrations found in the Marshall and Antrim formation waters in our study area (southern portion of the basin). Indeed, $\mathrm{Br}^{-}$content is negligible in evaporites. High $\mathrm{Br}^{-}$concentrations are the result of seawater evaporation and are thus expected to have its original source in underlying $\mathrm{Br}^{-}$-enriched basinal brines [e.g., Ging et al., 1996; McIntosh et al., 2004]. Indeed, brines from the Traverse formation (Figures $6 \mathrm{a}$ and $6 \mathrm{~b}$ ), a major carbonate aquifer underlying the Antrim shale have higher $\mathrm{Br}^{-}$and $\mathrm{Cl}^{-}$concentrations and plot along the seawater-evaporation curve (dashed line, Figure 6b) [McCaffrey et al., 1987], past halite saturation, indicating that their evolution is related to evaporated seawater [Wilson and Long, 1993b]. Samples from the Marshall and Antrim formations also plot along the seawater-evaporation curve (Figures $6 \mathrm{a}$ and $6 \mathrm{~b}$ ) and connect the fresh water and brine end-members, suggesting mixing of upwelling deep brines with recharge water within these shallower levels (Figure 6b). High $\mathrm{Cl}^{-}$and $\mathrm{Br}^{-}$contents in shallow waters (e.g., Glacial Drift and Marshall aquifer) are thus most likely transported through cross-formational flow from the underlying Traverse formation brines.

[43] As also previously suggested through estimation of He fluxes (section 5.4.2), mixing of deep brines with recharge fresh water seems to be absent at lower levels as indicated by the high $\mathrm{Cl}^{-}$ concentrations in place in these formations (e.g., Traverse Formation, Silurian) as well as its observed small variability range.

[44] $\mathrm{Na}^{+}$within the Marshall shows a similar trend to that of $\mathrm{Cl}^{-}$(Figures 6c and 6d), and is also likely the result of upwelling basinal brines from the Traverse Formation. An almost linear trend is also observed between $\mathrm{Ca}^{2+}, \mathrm{Mg}^{2+}, \mathrm{Sr}^{2+}$, and $\mathrm{K}^{+}$and $\mathrm{Br}^{-}$in the most concentrated brines within the Marshall and those of deeper formations (Figure 7), further indicative of a progressive evolution from the deepest brines (e.g., Silurian) into shallower ones (Marshall).

[45] In fresh and less concentrated waters (e.g., Glacial Drift and Marshall), $\mathrm{Ca}^{2+}, \mathrm{Mg}^{2+}, \mathrm{Sr}^{2+}$, and $\mathrm{K}^{+}$concentrations remain relatively constant with increasing $\mathrm{Br}^{-}$contents $\left(\mathrm{Br}^{-}<0.1 \mathrm{mM}\right)$. Indeed, and unlike $\mathrm{Na}^{+}$and $\mathrm{Cl}^{-}$which are directly related to $\mathrm{Br}^{-}$through formation of basinal brines, $\mathrm{Ca}^{2+}$, $\mathrm{Mg}^{2+}, \mathrm{Sr}^{2+}$, and $\mathrm{K}^{+}$in diluted waters are buffered by water-rock interactions [e.g., Szramek and Walter, 2004].

\subsection{Deeper Brine Signatures in Shallow Formation Waters}

[46] We have just shown that Glacial Drift and Marshall groundwaters carry the signature of the deeper Traverse brines. In earlier sections we have also shown that the observed $\mathrm{He}$ excess in the

Figure 7. $\mathrm{Ca}^{2+}, \mathrm{Mg}^{2+}, \mathrm{Sr}^{2+}$, and $\mathrm{K}^{+}$versus $\mathrm{Br}^{-}$concentrations for the Marshall aquifer (closed red circles, this study; open red circles, [Dannemiller and Baltusis, 1990]), the Glacial Drift (black crosses, Dannemiller and Baltusis [1990]), the Antrim Shale formation (open blue squares, McIntosh et al. [2004]), the Traverse formation (closed blue squares), the Richfield (open brown triangles), the Detroit River Group (open green triangles), and the Niagara/Salina formation (closed brown triangles) [Wilson and Long, 1993a, 1993b]. Both (a, c, e, and g) log-log and (b, d, f, and h) linear scales are shown. 


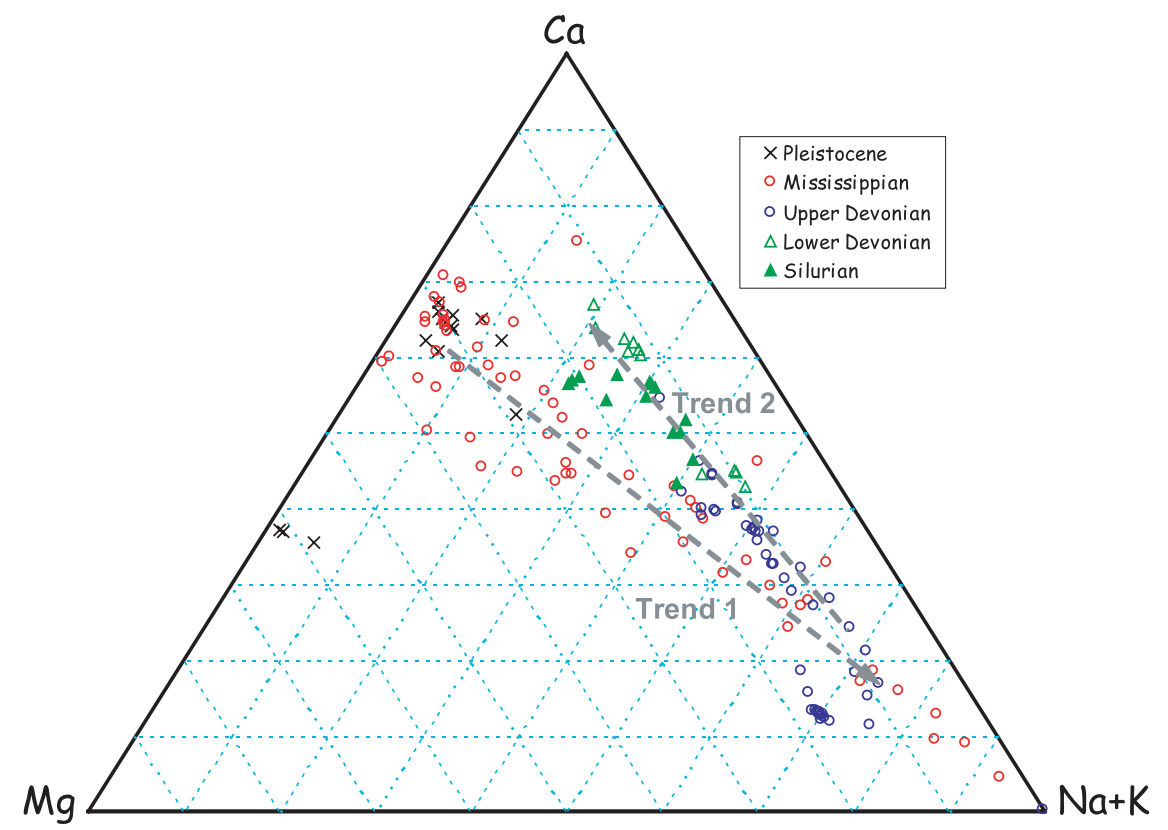

Figure 8. Ternary diagram showing mole percentage of $\mathrm{Ca}, \mathrm{Mg}$, and $\mathrm{Na}+\mathrm{K}$ in Michigan Basin formation waters: Pleistocene (Glacial Drift, black crosses), Mississippian (Marshall sandstone, open red circles), Upper Devonian (Antrim and Traverse formations, open blue circles), Lower Devonian (Richfield and Detroit River Group, open green triangles), and Silurian (Niagara/Salina formations, closed green triangle). Trends indicating evolution of chemical facies from fresh groundwater (Trend 1) to deeper brines (Trend 2) are also indicated.

Marshall originates from sources deeper than the Traverse formation, and suggested that high salinities observed in the Marshall are also likely to have a deeper origin.

[47] Because the environmental conditions required for such extreme seawater evaporation to take place during Late Devonian (e.g., Traverse Formation) are unlikely, Wilson and Long [1993a, 1993b] suggested that the latter might have been affected by the underlying Silurian brines. Indeed, such influence can be clearly observed between a diversity of ions and $\mathrm{Br}^{-}$(Figures 6 and 7). For example, Lower Devonian and Silurian brines present the highest $\mathrm{Cl}^{-}$and $\mathrm{Br}^{-}$concentrations and plot further along the seawater-evaporation curve, close to K-salt saturation, indicating a more extreme seawater evaporation. It is clear that Silurian and Traverse brines are not plotted as two isolated groups, but instead, Silurian brines evolve into the chemical composition of those of the Traverse group (Figure 6b). Major cations $\left(\mathrm{Na}^{+}, \mathrm{K}^{+}, \mathrm{Ca}^{2+}, \mathrm{Mg}^{2+}\right.$, and $\mathrm{Sr}^{2+}$ ) show a similar trend. This signature of deep Silurian brines into the Traverse Formation reinforces once again the presence of deep crossformational flow derived from $\mathrm{He}$ considerations.
[48] Michigan Basin brines have significantly enriched $\mathrm{Ca}^{2+}$, and depleted $\mathrm{Mg}^{2+}, \mathrm{Na}^{+}$, and $\mathrm{K}^{+}$ concentrations (Figures $6 \mathrm{~d}, 7 \mathrm{~b}, 7 \mathrm{~d}$, and $7 \mathrm{~h}$ ) with respect to modern seawater-evaporation curves [McCaffrey et al., 1987]. Extensive water-rock interactions have been proposed to explain these elemental differences from modern evaporated seawater (e.g., dolomitization for $\mathrm{Ca}^{2+}$-excess and $\mathrm{Mg}^{2+}$-deficit; albitization for $\mathrm{Ca}^{2+}$-excess and $\mathrm{Na}^{+}$-deficit; formation of new K-minerals for $\mathrm{K}^{+}$deficit [e.g., Wilson and Long et al., 1993a, 1993b; Davisson and Criss, 1996; Duffin, 1989]). However, these elemental differences could also be interpreted as the result of fundamentally different chemical compositions in ancient Silurian seawaters (e.g., seawater with higher $\mathrm{Ca}^{2+}$, lower $\mathrm{Mg}^{2+}$ and $\mathrm{Na}^{+}$concentrations [Brennan and Lowenstein, 2002]). Although no single process alone can account for the observed chemical compositions of these brines, such elemental differences with respect to modern evaporated seawater are found at almost all depths in the Michigan Basin (e.g., from Silurian to Mississippian formations). This suggests that brines at all depths may be genetically related as a result of upward crossformational flow. 


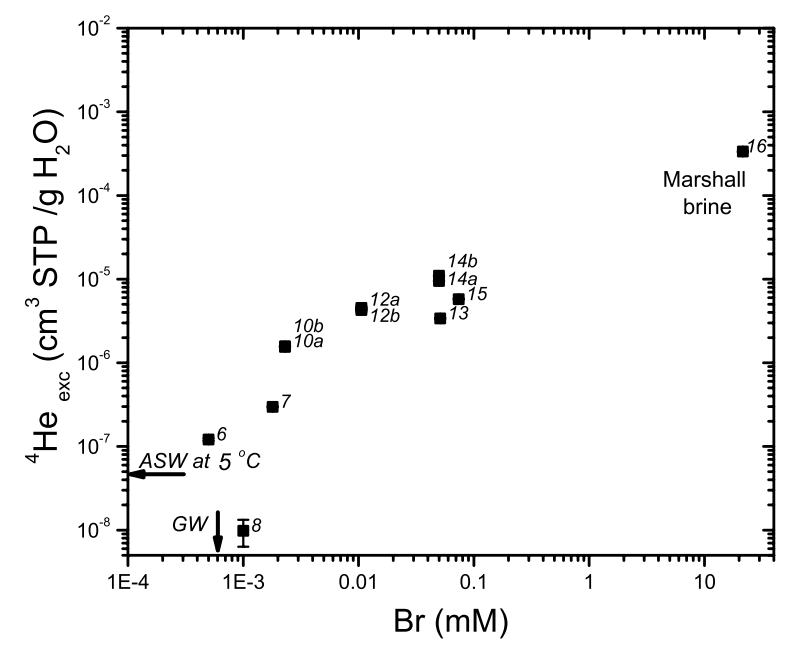

Figure 9. ${ }^{4} \mathrm{He}_{\text {exc }}$ versus $\mathrm{Br}^{-}$concentrations in the Marshall aquifer (this study). ASW ${ }^{4} \mathrm{He}$ concentration at $5^{\circ} \mathrm{C}$ [Ozima and Podosek, 2002] and average $\mathrm{Br}^{-}$concentration in shallow fresh groundwaters [Dannemiller and Baltusis, 1990] are indicated.

\subsection{Vertical Chemical Water Facies Evolution and $\mathrm{He}-\mathrm{Br}$ Relationship in the Marshall Aquifer}

[49] Overall, diluted waters in the Glacial Drift and Marshall aquifers are mostly $\mathrm{Ca}-\mathrm{Mg}-\mathrm{HCO}_{3}$ dominated and represent recharge water in which waterrock interactions with carbonates have occurred over time, while high saline waters have evolved into $\mathrm{Na}-\mathrm{Cl}$ facies due to incorporation of deeper brines (Trend 1, Figure 8). Upper Devonian strata are mostly $\mathrm{Na}-\mathrm{Cl}$ dominated and evolve progressively into $\mathrm{Na}-\mathrm{Ca}-\mathrm{Cl}$ facies (Devonian). The latter subsequently evolves into a dominant $\mathrm{Ca}-\mathrm{Na}-\mathrm{Cl}$ facies (Lower Devonian-Silurian; Trend 2, Figure 8).

[50] Although the Michigan Basin brines are geochemically compartmentalized [e.g., Martini, 1997], the above observations clearly show the influence of deep Silurian brines into the overlying strata, which likely results from upward crossformational flow. The positive correlation observed in the Marshall aquifer between excess $\mathrm{He}$ and $\mathrm{Br}^{-}$ (Figure 9), two very distinct conservative tracers, further reinforces this concept.

\section{Conclusions}

[51] We present helium data and major ion chemistry from the Marshall aquifer in southern Michigan. This shallow groundwater data set is subsequently interpreted in conjunction with major element data sets from deeper and shallower water levels previously analyzed in this area [Dannemiller and Baltusis, 1990; Wilson and Long, 1993a, 1993b; McIntosh et al., 2004].

[52] He excesses and isotopic ratios suggest the presence of tritiogenic ${ }^{3} \mathrm{He}$ in young waters in the Marshall aquifer. High He excesses in old groundwater samples are mostly of crustal origin (nucleogenic ${ }^{3} \mathrm{He}$ and radiogenic ${ }^{4} \mathrm{He}$ ) with the presence of a significant mantle He component in some samples. $\mathrm{He}$ excesses in the Marshall aquifer are unusually high for such shallow depths, and require a source external to the aquifer, partly supplied by underlying formations within the sedimentary sequence, partly from the crystalline basement. Calibration of $\mathrm{He}$ concentrations through an analytical model indicate that the high ${ }^{3} \mathrm{He}_{e x c}$ and ${ }^{4} \mathrm{He}_{\text {exc }}$ observed in the Marshall require He fluxes of $1 \times 10^{-13}$ and $1.6 \times$ $10^{-6} \mathrm{~cm}^{3}$ STP $\mathrm{cm}^{-2} \mathrm{yr}^{-1}$ for ${ }^{3} \mathrm{He}$ and ${ }^{4} \mathrm{He}$, respectively. These He fluxes are far greater than those reported in other sedimentary basins around the world at similar and far greater depths (e.g., Paris Basin, Gulf Coast Basin [Castro et al., 1998b; Castro, 2004]). Such high He fluxes present at such shallow depths within the Michigan Basin strongly suggest the presence of a dominant vertical water flow component, i.e., upward leakage, and further indicate that the impact of the horizontal flow component (e.g., recharge water) at depth is minor. Cross-formational flow is also likely responsible for the extremely high salinities present in the shallow subsurface of the Michigan Basin. The observed positive correlation between helium and bromide strongly suggests that these two very distinct conservative tracers both originate at greater depths, and further suggests that advection is the dominant transport mechanism within the basin. The occurrence of large-scale cross-formational flow is also consistent with the evolution displayed by the major ion chemistry throughout most of the sedimentary sequence (e.g., Silurian through Glacial Drift Sediments), indicating that solutes from shallow levels carry the signature of deep formation brines.

\section{Acknowledgments}

[53] The authors thank W. M. White and D. R. Hilton for the editorial handling of this manuscript, W. Aeschbach-Hertig and an anonymous reviewer for their reviews, David Westjohn for his assistance at providing well information, and Kathy Flemming for her assistance in the field. We also thank the numerous private and public well owners for having provided access to the wells for sampling. Acknowledgment is made to 
the Donors of the American Chemical Society Petroleum Research Fund for support of this research (PRF\# 38175-G8).

\section{References}

Ballentine, C. J. (1991), He, Ne and Ar isotopes as tracers in crustal fluids, Ph.D. dissertation, 216 pp., Univ. of Cambridge, Cambridge, UK.

Ballentine, C. J., and C. M. Hall (1999), Determining paleotemperature and other variables by using an error-weighted nonlinear inversion of noble gas concentrations in water, Geochim. Cosmochim. Acta, 63(16), 2315-2336.

Benson, B. B., and D. Krause (1980), Isotopic fractionation of helium during solution-A probe for the liquid-state, J. Solution Chem., 9(12), 895-909.

Brennan, S. T., and T. K. Lowenstein (2002), The major-ion composition of Silurian seawater, Geochim. Cosmochim. Acta, 66(15), 2683-2700.

Carpenter, A. B. (1978), Origin and chemical evolution of brines in sedimentary basins, Okla. Geol. Surv. Circ., 79, $60-77$.

Castro, M. C. (2004), Helium sources in passive margin aquifers-New evidence for a significant mantle ${ }^{3} \mathrm{He}$ source in aquifers with unexpectedly low in $s i t u{ }^{3} \mathrm{He} /{ }^{4} \mathrm{He}$ production, Earth Planet. Sci. Lett., 222(3-4), 897-913.

Castro, M. C., and P. Goblet (2003), Calibration of regional groundwater flow models: Working toward a better understanding of site-specific systemsWater Resour. Res., 39(6), 1172, doi:10.1029/2002WR001653.

Castro, M. C., A. Jambon, G. de Marsily, and P. Schlosser (1998a), Noble gases as natural tracers of water circulation in the Paris Basin: 1. Measurements and discussion of their origin and mechanisms of vertical transport in the basin, Water Resour. Res., 34(10), 2443-2466.

Castro, M. C., P. Goblet, E. Ledoux, S. Violette, and G. de Marsily (1998b), Noble gases as natural tracers of water circulation in the Paris Basin: 2. Calibration of a groundwater flow model using noble gas isotope data, Water Resour. Res., 34(10), 2467-2483.

Castro, M. C., M. Stute, and P. Schlosser (2000), Comparison of ${ }^{4} \mathrm{He}$ ages and ${ }^{14} \mathrm{C}$ ages in simple aquifer systems: Implications for groundwater flow and chronologies, Appl. Geochem., 15(8), 1137-1167.

Catacosinos, P. A., and P. A. J. Daniels (1991), Stratigraphy of Middle Proterozoic to Middle Ordovician formations of the Michigan Basin, Spec. Pap. Geol. Soc. Am., 256, 53-71.

Clark, S. P., Jr. (1966), Handbook of Physical Constants, Mem. Geol. Soc. Am., vol. 97, 587 pp., Geol. Soc. of Am., New York.

Clarke, W. B., W. J. Jenkins, and Z. Top (1976), Determination of tritium by mass-spectrometric measurement of ${ }^{3} \mathrm{He}$, Int. J. Appl. Radiat. Isotopes, 27(9), 515-522.

Dannemiller, G. T., and M. A. Baltusis Jr. (1990), Physical and chemical data for ground water in the Michigan Basin, 1986-1989, 155 pp, U.S. Geol. Surv. Open File Rep., 90368 .

Davisson, M. L., and R. E. Criss (1996), Na-Ca-Cl relations in basinal fluids, Geochim. Cosmochim. Acta, 60(15), 27432752.

Dorr, J. A., Jr., and D. F. Eschman (1970), Geology of Michigan, 476 pp., Univ. of Michigan Press, Ann Arbor, Mich.

Duffin, M. E. (1989), Nature and origin of authigenic K-feldspar in Precambrian basement rocks of the North American midcontinent, Geology, 17(8), 765-768.
Fisher, J. H., M. W. Barratt, J. B. Droste, and R. H. Shaver (1988), Michigan Basin, in Sedimentary Cover-North American Craton, edited by L. L. Sloss, pp. 361-382, Geol. Soc. of Am., Boulder, Colo.

Fontes, J. C., and J. M. Garnier (1979), Determination of the initial ${ }^{14} \mathrm{C}$ activity of the total dissolved carbon-Review of the existing models and a new approach, Water Resour. Res., 15(2), 399-413.

Fontes, J. C., and J. M. Matray (1993), Geochemistry and origin of formation brines from the Paris Basin, France. 1. Brines associated with Triassic salts, Chem. Geol., 109(14), 149-175.

Freeze, R. A., and J. A. Cherry (1979), Groundwater, 604 pp, Prentice-Hall, Upper Saddle River, N. J.

Gieskes, J. M., and W. C. Rogers (1973), Alkalinity determination in interstitial waters of marine sediments, J. Sediment Petrol., 43(1), 272-277.

Ging, P. B., D. T. Long, and R. W. Lee (1996), Selected geochemical characteristics of ground water from the Marshall aquifer in the central Lower Peninsula of Michigan, U.S. Geol. Surv. Water Resour. Invest., Rep. 94-4220, 19 pp.

Graham, D. (2002), Noble gas isotope geochemistry of midocean ridge and ocean island basalts: Characterization of mantle source reservoirs, Rev. Mineral. Geochem., 47, 247-317.

Heaton, T. H. E., and J. C. Vogel (1981), Excess air in groundwater, J. Hydrol., 50(1-3), 201-216.

Hilton, D. R., and D. Porcelli (2003), Noble gases as mantle tracers, in The Mantle and Core, vol. 2, Treatise on Geochemistry, edited by H. D. Holland and K. K. Turekian, pp. 277-318, Elsevier, New York.

Hilton, D. R., T. P. Fischer, and B. Marty (2002), Noble gases and volatile recycling at subduction zones, Rev. Mineral. Geochem., 47, 319-370.

Hinze, W. J., R. L. Kellogg, and N. W. O'Hara (1975), Geophysical studies of basement geology of Southern Peninsula of Michigan, AAPG Bull., 59(9), 1562-1584.

Kolak, J. J., D. T. Long, J. M. Matty, G. J. Larson, D. F. Sibley, and T. B. Councell (1999), Ground-water, large-lake interactions in Saginaw Bay, Lake Huron: A geochemical and isotopic approach, Geol. Soc. Am. Bull., 111(2), 177-188.

Long, D. T., T. P. Wilson, M. J. Takacs, and D. H. Rezabek (1988), Stable-isotope geochemistry of saline near-surface ground water; east-central Michigan Basin, Geol. Soc. Am. Bull., 100(10), 1568-1577.

Ma, L., M. C. Castro, and C. M. Hall (2004), A late Pleistocene-Holocene noble gas paleotemperature record in southern Michigan, Geophys. Res. Lett., 31, L23204, doi:10.1029/ 2004GL021766.

Mandle, R. J., and D. B. Westjohn (1989), Geohydrologic framework and ground-water flow in the Michigan basin, in Regional Aquifer Systems of the United States-Aquifers of the Midwestern Area, AWRA Monogr. Ser., vol. 13, edited by L. A. Swain and A. I. Johnson, pp. 83-109, Am. Water Resour. Assoc., Middleburg, Va.

Martini, A. M. (1997), Hydrogeochemistry of saline fluids and associated water and gas, Ph.D. dissertation, 237 pp., Univ. of Mich., Ann Arbor.

McCaffrey, M. A., B. Lazar, and H. D. Holland (1987), The evaporation path of seawater and the coprecipitation of $\mathrm{Br}^{-}$ and $\mathrm{K}^{+}$with halite, J. Sediment. Petrol., 57(5), 928-937.

McIntosh, J. C., L. M. Walter, and A. M. Martini (2004), Extensive microbial modification of formation water geochemistry: Case study from a midcontinent sedimentary basin, United States, Geol. Soc. Am. Bull., 116(5-6), $743-759$ 
Menuge, J. F., T. S. Brewer, and C. M. Seeger (2002), Petrogenesis of metaluminous A-type rhyolites from the St. Francois Mountains, Missouri and the Mesoproterozoic evolution of the southern Laurentian margin, Precambrian Res., 113(3-4), 269-291.

Morrison, P., and J. Pine (1955), Radiogenic origin of the helium isotopes in rock, Ann. N. Y. Acad. Sci., 62(3), 71-92.

Ozima, M., and F. A. Podosek (2002), Noble Gas Geochemistry, 2nd ed., 286 pp., Cambridge Univ. Press, New York.

Parker, R. L. (1967), Composition of Earth's crust, data of geochemistry, U.S. Geol. Surv. Prof. Pap., 440-D, pp. 1-19.

Patriarche, D., M. C. Castro, and P. Goblet (2004), Large-scale hydraulic conductivities inferred from three-dimensional groundwater flow and ${ }^{4} \mathrm{He}$ transport modeling in the Carrizo aquifer, Texas, J. Geophys. Res., 109, B11202, doi:10.1029/ 2004JB003173.

Roether, W. (1967), Estimating the tritium input to groundwater from wine samples: Groundwater and direct run-off contribution to central European surface waters, in Isotopes in Hydrology, pp. 73-91, Int. At. Energy Agency, Vienna.

Saar, M. O., M. C. Castro, C. M. Hall, M. Manga, and T. P. Rose (2005), Quantifying magmatic, crustal, and atmospheric helium contributions to volcanic aquifers using all stable noble gases: Implications for magmatism and groundwater flow, Geochem. Geophys. Geosyst., 6, Q03008, doi:10.1029/2004GC000828.

Schlosser, P., M. Stute, C. Sonntag, and K. O. Munnich (1989), Tritiogenic ${ }^{3} \mathrm{He}$ in shallow groundwater, Earth Planet. Sci. Lett., 94(3-4), 245-256.

Siegel, D. I., K. A. Lesniak, M. Stute, and S. Frape (2004), Isotopic geochemistry of the Saratoga springs: Implications for the oigin of solutes and source of carbon dioxide, Geology, 32(3), 257-260.

Solomon, D. K., A. Hunt, and R. J. Poreda (1996), Source of radiogenic helium 4 in shallow aquifers: Implications for dating young groundwater, Water Resour. Res., 32(6), $1805-1814$

Speece, M. A., T. D. Bowen, J. L. Folcik, and H. N. Pollack (1985), Analysis of temperatures in sedimentary basins; the Michigan Basin, Geophysics, 50(8), 1318-1334.

Stueber, A. M., and L. M. Walter (1991), Origin and chemical evolution of formation waters from Silurian-Devonian strata in the Illinois Basin, USA, Geochim. Cosmochim. Acta, 55(1), 309-325.

Stuiver, M., and P. J. Reimer (1993), Extended ${ }^{14} \mathrm{C}$ data-base and revised Calib $3.0{ }^{14} \mathrm{C}$ age calibration program, Radiocarbon, 35(1), 215-230.

Stute, M., C. Sonntag, J. Deak, and P. Schlosser (1992), Helium in deep circulating groundwater in the Great Hungarian
Plain: Flow dynamics and crustal and mantle helium fluxes, Geochim. Cosmochim. Acta, 56(5), 2051-2067.

Szramek, K., and L. M. Walter (2004), Impact of carbonate precipitation on riverine inorganic carbon mass transport from a mid-continent, forested watershed, Aquat. Geochem., 10(1-2), 99-137.

Tolstikhin, I., B. E. Lehmann, H. H. Loosli, and A. Gautschi (1996), Helium and argon isotopes in rocks, minerals, and related groundwaters: A case study in northern Switzerland, Geochim. Cosmochim. Acta, 60(9), 1497-1514.

Torgersen, T. (1980), Controls on pore-fluid concentration of ${ }^{4} \mathrm{He}$ and ${ }^{222} \mathrm{Rn}$ and the calculation of ${ }^{4} \mathrm{He}^{222} \mathrm{Rn}$ ages, J. Geochem. Explor., 13(1), 57-75.

Torgersen, T., and W. B. Clarke (1985), Helium accumulation in groundwater; I, An evaluation of sources and the continental flux of crustal ${ }^{4} \mathrm{He}$ in the Great Artesian Basin, Australia, Geochim. Cosmochim. Acta, 49(5), 1211-1218.

Torgersen, T., and G. N. Ivey (1985), Helium accumulation in groundwater; II, A model for the accumulation of the crustal ${ }^{4} \mathrm{He}$ degassing flux, Geochim. Cosmochim. Acta, 49(11), $2445-2452$.

Torgersen, T., S. Drenkard, M. Stute, P. Schlosser, and A. M. Shapiro (1995), Mantle helium in ground waters of eastern North America: Time and space constraints on sources, Geology, 23(8), 675-678.

Van Schmus, W. R. (1992), Tectonic setting of the Midcontinent Rift system, Tectonophysics, 213, 1-15.

Vugrinovich, R. (1986), Patterns of regional subsurface fluid movement in the Michigan Basin, Open File Rep. 86-6, 27 pp., Geol. Surv. Div., Mich. Dep. of Nat. Resour., Lansing.

Weaver, T. R., S. K. Frape, and J. A. Cherry (1995), Recent cross-formational fluid flow and mixing in the shallow Michigan Basin, Geol. Soc. Am. Bull., 107(6), 697-707.

Weiss, R. F. (1968), Piggyback sampler for dissolved gas studies on sealed water samples, Deep Sea Res. Oceanogr. Abstr., 15(6), 695-699.

Westjohn, D. B., and T. L. Weaver (1996), Hydrogeologic framework of Mississippian rocks in the central Lower Peninsula of Michigan, U.S. Geol. Surv. Water Resour. Invest., Rep. 94-4246, 46 pp.

Wilson, T. P. (1989), Origin and Geochemical Evolution of the Michigan Basin Brine, 272 pp., Mich. State Univ., East Lansing.

Wilson, T. P., and D. T. Long (1993a), Geochemistry and isotope chemistry of $\mathrm{Ca}-\mathrm{Na}-\mathrm{Cl}$ brines in Silurian strata, $\mathrm{Mi}$ chigan Basin, U.S.A., Appl. Geochem., 8(5), 507-524.

Wilson, T. P., and D. T. Long (1993b), Geochemistry and isotope chemistry of Michigan Basin brines: Devonian formations, Appl. Geochem., 8(2), 81-100. 